\title{
Estimating Bargaining-related Tax Advantages of Multinational Firms*
}

\author{
Peter H. Egger ${ }^{\dagger} \quad$ Nora M. Strecker ${ }^{\ddagger} \quad$ Benedikt Zoller-Rydzek ${ }^{\S}$
}

February 6, 2019

\begin{abstract}
The effective corporate profit tax rates (ETRs) of multinational enterprises (MNEs) are in general lower than those of national enterprises (NEs). In this paper, we argue that the bargaining power of MNEs is an important factor in explaining these differences beyond profit shifting. First, larger and more profitable firms are more valuable for tax authorities through, e.g., higher tax revenues and employment. In threatening to move their operations to other jurisdictions, larger firms, and specifically MNEs, may be able to extract greater tax deductions. This results in a regressive ETR schedule for MNEs and NEs. Second, MNEs face arguably lower costs to relocate their business (or profits) to foreign countries with a lower tax rate than NEs. This improves MNEs' threat point in bargaining and enables them further to extract higher tax deductions than NEs. To empirically quantify the importance of bargaining on the tax gap between MNEs and NEs, it is elemental to rigorously condition on the determinants of MNE status, profit taxation, as well as possible profit-shifting activities. To that end, we use French firm-level data and entropy balancing on the joint determinants of MNE status (including the possibility of profit shifting) and a firm's ETR. We find that the empirical regressivity of the French tax schedule reduces French MNEs' ETRs by 2.52 percentage points on average due to their larger size, while the relocation threat of the same firms reduces their ETR by 3.58 percentage points relative to comparable NEs. The former is a tax advantage that any firm (MNE or NE) of the same size could obtain, while the latter is specific to MNEs and beyond the reach of NEs.
\end{abstract}

Keywords: Profit taxation; Multinational firms; Entropy balancing.

JEL-codes: H25; H26; F23; C21.

\footnotetext{
*The authors would like to thank the editor Matilde Bombardini and two anonymous referees for numerous helpful comments on an earlier version of the paper. The authors gratefully acknowledge financial support by the Swiss National Science Foundation (SNSF) and the MTEC Foundation. The authors are also grateful to comments from participants at conference sessions of the European Economic Association in Geneva, the International Institute of Public Finance at Lake Tahoe, the 16th Journées Louis-André Gérard-Varet in Aix-en-Provence, and seminar participants at KOF ETH Zurich and the Study Center Gerzensee. In particular, the authors are grateful to Dhammika Dharmapala, Mindy Herzfeld, James Hines, Jr., Farid Toubal, and Ian Wooton for helpful advice.

$\dagger$ Affiliation: ETH Zurich, CEPR, CESifo, Leverhulme Centre for Research on Globalisation and Economic Policy (GEP) at the University of Nottingham, and Oxford University Centre for Business Taxation (CBT). Address: ETH Zurich, KOF, Leonhardstrasse 21, LEE G 116, 8092 Zurich, Switzerland. E-mail: egger@kof.ethz.ch

$\ddagger$ Affiliation: ETH Zurich. Address: ETH Zurich, KOF, Leonhardstrasse 21, LEE G 129, 8092 Zurich, Switzerland. E-mail: strecker@kof.ethz.ch

$\S$ Affiliation: ETH Zurich, International Management Institute, School of Management and Law, Zurich University of Applied Sciences (ZHAW). Address: Zurich University of Applied Sciences, School of Management and Law, Stadthausstrasse 14, P.O. Box, 8401 Winterthur, Switzerland. E-mail: benedikt.zoller@zhaw.ch.
} 


\section{Introduction}

Multinational enterprises (MNEs) are an integral part of the world economy. They actively engage in innovation, investment, and trade, provide valuable employment, and generate extensive profits. This is why many countries run campaigns to lure them into their jurisdictions. However, in the public mind and debate, MNEs are frequently accused of avoiding, if not evading, taxation, thus reducing the tax base of their host countries and causing welfare losses. Individual governments and international organizations - in particular the OECD through its Base Erosion and Profit Shifting (BEPS) initiative - have recently begun to try and limit the undesirable tax avoidance and evasion strategies of firms, primarily of MNEs, in an attempt to limit tax-avoidance-related welfare losses. These internationally coordinated efforts mainly aim at profit shifting activities of MNEs related to transfer pricing, debt shifting, and royalty payments.

The reduction of MNEs' tax bills via profit shifting channels is well documented. However, this paper focuses on a less explored channel: bargaining. In nearly every European country and around the world, firms are able to bargain with local governments or tax authorities over possible deductions in order to reduce their tax bill. In this bargaining game, MNEs are favored to firms that only operate domestically, leading to relatively higher tax savings for MNEs. This directly undermines the efforts of international organizations, such as the OECD and the EU, to limit tax avoidance. Specifically, we think of the bargaining-related tax gap between MNEs and national enterprises (NEs) as a composite of three ingredients: one non-discriminatory element available to all firms and two discriminatory elements only available to MNEs. The two discriminatory elements relate to MNEs' operations of foreign affiliates: (i) foreign affiliates enable profit shifting to low-tax countries (tax avoidance and evasion); and (ii) MNEs are more credibly footloose than NEs which adds to their relative bargaining power at any given firm size and profitability. The non-discriminatory element flows from the empirical regressivity of tax schedules due to the greater bargaining power of larger and more profitable firms as such and leads to increased tax savings for MNEs (see Rego, 2003; Slemrod, 2004), solely rooted in their, on average, larger size and greater profitability relative to NEs (see Markusen, 2002; Helpman et al., 2004). These discriminatory and non-discriminatory elements have not been rigorously disentangled in earlier work on the tax gap between MNEs and NEs, which instead largely focused on analyzing and quantifying profit shifting. The goal of the present paper is to fill this gap and, by focusing on the bargaining-related aspects of tax savings, disentangle and quantify the discriminatory and non-discriminatory bargaining-related tax savings of MNEs using French firm-level data.

Figure 1 documents the differences in the average effective tax rate (ETR), computed as the ratio of annual corporate profit taxes paid over annual before-tax profits between 2007 and 2012 from unconsolidated accounts, for three distinct firm types in France as recorded in Bureau van Dijk's ORBIS data set: MNEs, multi-entity NEs, and single-entity NEs, where an entity is an independent unit of operation. The figure suggests that MNEs face systematically lower ETRs than both types of NEs on average and that the average ETRs of multi-entity NEs were somewhat lower than those of single-entity NEs. Specifically, the ETR of MNEs is on average 3.42 percentage points lower than that of multi-entity NEs (with a standard error of $0.30)$.

We argue that the tax gap between MNEs and NEs does not only root in tax avoidance through profit shifting or (illegal) tax evasion, but also in the difference in the bargaining power between MNEs and NEs. ${ }^{1}$

\footnotetext{
${ }^{1}$ MNEs may additionally be bargaining over employee-borne taxation. Egger et al. (2013) find evidence of a significant effect of both employee-borne and corporate profit taxes on the international location choice of headquarters.
} 


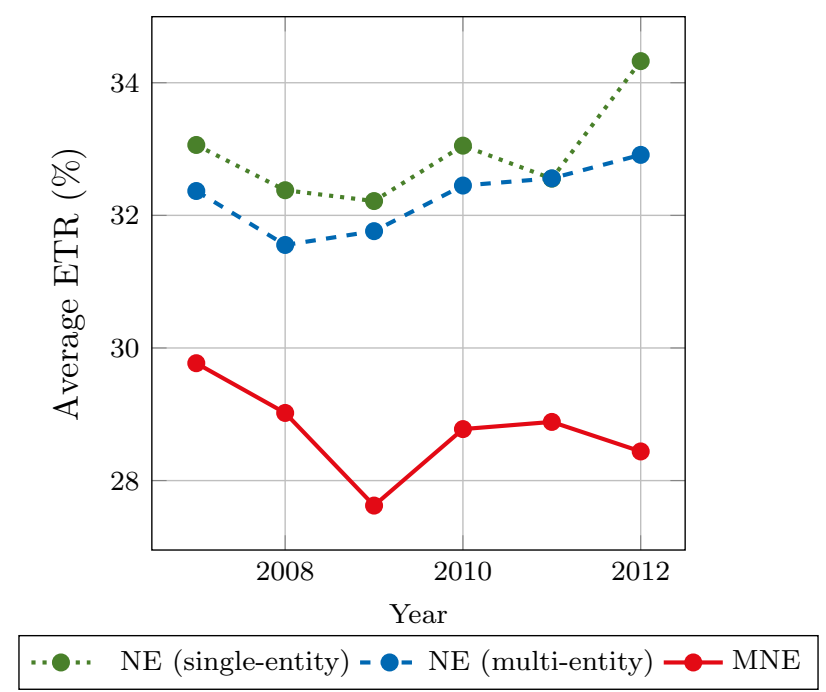

Figure 1: Average ETR By firm type Between 2007-2012

In this vein, Rego (2003) and Slemrod (2004) provide evidence that tax savings are positively correlated with firms' pre-tax profits, suggesting that the effective tax rate, ETR, declines with pre-tax profits, i.e., the ETR schedule of firms is regressive. Egger et al. (2010) show that MNEs have significant tax savings relative to comparable NEs even for a given pre-tax profit level. Consistent with these empirical findings we develop a stylized theoretical model in Section 3 that will guide our later estimation. Specifically, the model suggests that firms with higher pre-tax profits are in a better bargaining position and, hence, the empirically observable ETR schedule is regressive. In conjunction with the well-established fact of a greater profitability of MNEs relative to NEs, we are able to identify the non-discriminatory element, which we refer to as the size effect on the tax gap between MNEs and NEs. The discriminatory element, the footlooseness effect of MNEs relative to NEs, arises from (everything else equal) lower fixed costs to relocate entities (and/or their profits) into countries with lower tax rates.

The aforementioned decomposition requires comparing MNEs to virtually identical NEs over an array of joint determinants of MNE status and profits. Doing so is potentially beyond the reach of linear regression and even of unconstrained, nonparametric econometric models, such as simple propensity score matching. This is because such unconstrained models do not ensure that the tax gap is computed from sets of treated (MNE) and control (NE) firms whose characteristics are distributed identically. To overcome this problem and ensure comparability, we apply entropy balancing, as suggested by Hainmueller (2012) and Hainmueller and Xu (2013), that permits an estimation of the causal effects of MNE status on ETRs through bargaining, conditional on profit-shifting-related tax avoidance and other attributes. To the best of our knowledge, this approach has not been previously applied in the context of self-selection into MNE status. The present paper employs this framework since the array of determinants of MNE status and firms' (including MNEs') tax payments are largely overlapping, if not the same, and observable. Further, we can show that the distributions of the respective observables vary widely between MNEs and NEs so that conditioning on a compact function of these characteristics (e.g., a linear index or a nonlinear index such as the propensity score of MNE status) does not sufficiently balance these moments as would be required to ensure identification of the average (causal) treatment effect of MNE status on profit tax payments in such frameworks (see Section $\mathrm{C}$ of the online appendix). 
France, despite its recent crackdowns and raids on suspected, tax-avoiding and tax-evading MNEs (most recently on the tax structures of Amazon, Apple, Google, and other well-known MNEs, see Brinded, 2013) and notwithstanding its reputation for difficult tax negotiations, is a prime location for such an analysis. France's tax system is based on two codes, the general tax code (Code Général des Impôts) and the tax procedure code (Livre des procédures fiscales), and taxes corporate profits under the territoriality principle. The corporate tax code does not provide for tax holidays. However, it explicitly provides for a host of tax deductions, such as the deduction of losses in foreign subsidiaries (starting from January 1, 2009), of $95 \%$ of dividends received from subsidiaries, or of research and development expenditures. Additionally, the corporate tax code allows for tax relief for domestic mergers and international mergers upon approval. France applies controlled foreign company legislation rules, anti-avoidance provisions, tax consolidation regimes, and regulations on payments made to subsidiaries in tax havens. ${ }^{2}$

Akin to the majority of European countries and the United States, the French tax authorities offer advance tax rulings, essentially allowing firms to negotiate their tax deductions before the first Euro is earned (see Van de Velde, 2015 and Waerzeggers and Hillier, 2016, for an extensive overview of tax rulings within Europe). Huesecken and Overesch (2015) provide some evidence that these advance rulings lead to significantly lower tax payments. While few of these rulings enter the public awareness, there are several suspected cases of advance rulings that were discussed more widely (e.g., Amazon opened distribution centers in France, adding valuable jobs to the economy and revenue to state coffers after prolonged negotiations with the government, see Le Monde, 2012; Google opened its Paris office after a big push by the Sarkozy government, see Le Monde, 2010), with a handful of disclosed cases (e.g., Vivendi Universal SA, a mass media conglomerate headquartered in France, was permitted to offset the profits from its semi-owned subsidiaries with losses incurred in 2002, significantly reducing Vivendi's tax bill, see ITRWeek, 2004). These tax rulings are binding for the tax authorities, becoming law and being subsequently available to all firms in the same, often quite narrowly defined, situations. However, they are not binding for firms, who can elect to alter their ex-post tax optimization strategies. Given the size of the firms in question, we abstract from illegal tax evasion as the reputational losses and the massive increase in public, private, and governmental scrutiny make this option rather unattractive. Moreover, these firms can afford to design their tax structures in a way that remains within the legal space. ${ }^{3}$

While the number of tax audits remained largely constant in France between 2007 and 2012, coincidentally a time span which coincides with the Sarkozy presidency, the number of penalties imposed dropped at the beginning of the period and only increased after the beginning of the Hollande presidency (see Direction Générale des Finances Publiques, 2016a), after the passage of the Anti-tax Fraud Act in December 2013, which expanded the investigative powers of the French tax authorities and increased penalties (see Direction de l'Information Légale et Administrative, 2013). In the last few decades, the French state's investment strategy in the private sector has been to opt for non-voting shares in private firms over voting stocks (see Clift, 2012). ${ }^{4}$ This suggests that French tax authorities are (at least indirectly) linked to French politics, a fact that might be viewed as an important ingredient in the making of French industrial policy.

\footnotetext{
${ }^{2}$ See Direction Générale des Finances Publiques (2016b) for an extensive overview of aspects of the French tax system.

${ }^{3}$ There is also a steady flow of personnel between the private sector and the public sector, a phenomenon which is often referred to as the revolving door in the United States or as pantouflage in France. This exchange means that MNEs with their higher profits are willing and able to hire former government members and officials and gain access to their expertise and network to aid their negotiating positions.

${ }^{4}$ Between the end of World War II and the mid 1970s, the French government pursued so-called dirigiste policies, where the state was intricately linked and heavily invested in the private sector and directed the decisions of firms through the creation of national champions, what might today be considered a public-private partnership.
} 
The actual and possible connections and interactions between MNEs and tax authorities imply that the tax bargaining can be considered a government-assisted form of tax avoidance, among the many other forms of tax avoidance. In fact, France has been investigated and sued by the European Commission for providing French firms (e.g., France Telecom and the operators of France's grands ports maritime and the Port of Paris) with illegal state aid in the form of tax exemptions, see European Commission (2016) and Cullen (2006). However, it must be noted that the other, more conventional, forms of tax avoidance generally flow through profit shifting, widening the gap between realized and declared profits, while tax bargaining leads to a reduction of the tax rate on declared profits. ${ }^{5}$ The results presented below indicate that, on average and after conventional profit shifting, French MNEs earn 1.53 million more in pre-tax profits than comparable NEs on average. Due to the effectively regressive French corporate tax schedule, this translates into a merely size-related average reduction of an MNE's ETR by 2.52 percentage points relative to a comparable NE. ${ }^{6}$ The direct, bargaining-related effect of being an MNE on the ETR due to MNEs' greater mobility, controlling for pre-tax profits, amounts to a 3.58 percentage-point reduction of the ETR on average. Thus, on average, MNE status reduces the ETR by 6.1 percentage points, conditional on (i.e., after) profit shifting. This effect is mainly driven by firms in the highest quintile of the pre-tax profit distribution.

The remainder of the paper is structured as follows. Section 2 discusses the related literature. Section 3 outlines a stylized model of bargaining over a representative firm's tax deductions. Section 4 describes the data and the estimation strategy and presents the empirical results. Section 5 is devoted to a range of robustness tests. The last section concludes.

\section{Related literature}

\subsection{Sources of MNEs' tax savings}

The public finance literature largely places the difference in ETRs between MNEs and NEs at the door of profit shifting (see Huizinga and Laeven, 2008; Schindler and Schjelderup, 2013) and its channels through which MNEs reduce their corporate tax payments, namely transfer pricing (see Davies et al., 2018), debt shifting (see Egger et al., 2014), and royalty payments (see Karkinsky and Riedel, 2012; Griffith et al., 2014 among others). Konrad and Stolper (2016) show under which conditions the tax havens opposed by the OECD and the G20 are able to exist, which makes the aforementioned profit shifting methods possible. Kopczuk (2006) argues that the complexity of the tax law actually makes tax avoidance and shifting more likely. However, while interesting in itself, profit shifting is not the focus of the present paper, as it has been and still is at the heart of a sizable literature on tax avoidance. In the present paper, we take these profitshifting channels into consideration by controlling for observables that capture them, namely cross-border trading, debt, and intangible asset holdings, without putting them to the fore of the analysis.

One strand of earlier work addresses aspects of tax savings that are related to firm size. For instance, Grubert and Slemrod (1998), Rego (2003), Slemrod (2004), and Habu (2017) argue that economies of scale make it more profitable for MNEs to seek out loop holes in the tax code to reduce their ETRs. Alternatively,

\footnotetext{
${ }^{5}$ Several studies have analyzed conventional profit shifting across the globe. E.g., Tørsl $\varnothing \mathrm{v}$ et al. (2018) estimates that, at the aggregate level, French MNEs shifted approximately 32 billion USD in profits into tax havens in 2015, which involved an estimated loss in forgone French corporate tax revenues of $21 \%$.

${ }^{6}$ As indicated above, while the statutory tax rate on corporate profits is not regressive in France, French tax law does provide for numerous deductions and allowances resulting in an empirically regressive ETR, absent of any profit shifting activities.
} 
Richter et al. (2009) find that increased lobbying expenditures lead to lowered ETRs in a panel of U.S. firms. These arguments suggest that the larger size of MNEs matters for the affordability of some fixed costs associated with tax planning or lobbying. Along this line of thinking, there have been analyses of negotiation- and lobbying-related tax savings of MNEs relative to NEs. The results in Riedel and Simmler (2018) regarding the tax setting in German municipalities suggest that a larger business tax base (i.e., many or large firms present in a particular location) and a high concentration of firms are associated with lower business tax rates at the regional level. A further reason for the profit tax savings of MNEs relates to their greater credibility of threatening footlooseness than is the case with NEs. Vandenbussche and Tan (2005) explore the differences in ETRs between Belgian MNEs and NEs. Their findings suggest that MNEs have better outside options than NEs, which leads to a higher bargaining power and lower taxes relative to NEs. Huesecken and Overesch (2015) show that advance tax rulings (which are tailor-made for MNEs) significantly decrease the tax payments of MNEs relative to NEs. As such, advance tax rulings are essentially a nonstatutory instrument of tax competition, which itself has been well studied (see Devereux et al., 2002; Hines, 1999 among others), given the importance of MNEs in the global economy. All of these results suggest that larger firms - in particular, larger MNEs - benefit from their size and economic power in terms of reduced ETRs, beyond mere profit shifting.

Overall, while there is much documentation of the effective tax savings of MNEs, their magnitude is heavily debated and may depend on the setting and respective tax authorities. For instance, the results in Egger et al. (2010) suggest that, among European firms, the absolute tax payments of MNEs are lower than those of comparable NEs, while the results in Dyreng et al. (2017) suggest that U.S. MNEs indeed face a higher ETR than U.S. NEs.

\subsection{Econometric approach towards estimating the tax savings effect of being an MNE}

In quantifying the effect of the previously noted tax competition on MNE performance, on foreign direct investment, and on location choice, previous work such as in Hines (1999), Gresik (2001), and Devereux and Maffini (2007) relied on panel data to compare firms or aggregate outcomes just prior to and immediately after a tax or law change and across locations (e.g., Dharmapala and Riedel, 2013). Alternatively, other work compared the outcomes of MNEs and NEs within a given location (see Jog and Tang, 2001; Buettner et al., 2009; Egger et al., 2010).

In either case, the prevailing framework is based on a selection on (location- and/or firm-level) observables and either a linear (see Becker and Riedel, 2012) or nonlinear, even nonparametric, (see Egger et al., 2010) index of comparability in regression frameworks. Either econometric approach rests on the idea that, upon conditioning on the (linear or nonlinear) index of observables, any further difference between MNEs and NEs in terms of their (normalized or unnormalized) profit tax payments accrues to a quasi-random assignment of the MNE-versus-NE status. However, for this to hold, either approach requires that the distribution of observables behind the index is the same among MNEs (the treated) and NEs (the controls). Otherwise, some of the differences in the profit-tax outcomes that in fact accrue to differences in the distribution of observable joint determinants of MNE status and tax outcome may be misascribed to MNE status only, which may in turn lead to biased estimates of the average treatment effect of being an MNE on tax outcomes. Econometrically, one would generically refer to such a case as one of a lack of covariate balancing. 
One approach to overcome this lack of covariate balancing in a selection-on-observables framework has been proposed by Hainmueller (2012) and Hainmueller and Xu (2013). Rather than assuming such balancing (as in regression approaches or propensity score matching) and testing against it ex post, Hainmueller's entropy balancing enforces covariate balancing in a constrained, nonlinear estimation approach. In a first step, weights are obtained for each targeted moment of the observables when considering treated and control (in our case, MNE and NE, respectively) observations subject to balancing constraints. In a second step, these weights are used in a weighting regression approach, where the outcome is regressed on the treatment indicator (here, MNE status) to estimate the average treatment effect on outcome. Notice that linear regression, propensity score matching, and other approaches based on the idea of selection on observables can be portrayed as special cases of weighting regression approaches towards the estimation of average treatment effects on outcome (see Wooldridge, 2007).

\section{$3 \quad$ A stylized model of tax bargaining}

We are interested in isolating the advantages of being an MNE above and beyond the effects of profit shifting. In spite of being at odds with many supranational agreements and the desire for policy transparency, advance tax rulings provide opportunities for unequal treatment of firms by national tax authorities and open the door to tax bargaining by firms. In this section, we develop a stylized theoretical model of tax bargaining that serves to inform our estimation. We assume that firms are able to directly negotiate their possible tax deductions and, by this, their ETRs. For simplicity, we do not differentiate between negotiations over the fraction of profits that is subject to the domestic tax from those over the ETR, as the outcome would be isomorphic. $^{7}$

Formally, we assume that national tax authorities and a generic firm $i$ bargain over the firm's deductions from its tax base, $D_{i}$, taking the statutory tax rate, $\tau$, as given. Firm $i$ 's net profits are then determined as

$$
\pi_{i}^{n}=(1-\tau) \pi_{i}+\tau D_{i}
$$

where $\pi_{i}$ are pre-tax profits. The government's tax revenues per firm, $T_{i}$, are then

$$
T_{i}=\tau\left(\pi_{i}-D_{i}\right)
$$

The firm and the government engage in Nash bargaining over the amount of deductions, $D_{i}$, where $\alpha \in[0,1]$ is the bargaining power of the government and $(1-\alpha)$ is the bargaining power of the firm. For simplicity we assume that $\alpha$ is not firm- or country-specific. Let us denote the outside option of the firm, i.e., the net profits a firm can generate by relocating its operations to a foreign country with effective tax rate $\mathrm{ETR}_{i}^{\prime}$, by $\left(1-\operatorname{ETR}_{i}^{\prime}\right) \pi_{i}-F_{i}$. For simplicity, we assume that the foreign country is passive. Thus, before-tax profits would be the same as at the outset after relocating, and $\mathrm{ETR}_{i}^{\prime}$ will be the firm's effective tax rate abroad. Relocating would come at a fixed cost, $F_{i}$, which we assume to depend on the firm's MNE status. Since MNEs have already established operations abroad, we assume that MNEs' fixed costs of relocating their

\footnotetext{
${ }^{7}$ In France and elsewhere, MNEs can negotiate the portion of their profits which will be subject to domestic taxes (see Bergin, 2012). In fact, with the exception of Slovakia, every EU and EFTA country has specific provisions for advance tax rulings.
} 
operations are significantly lower than those of NEs, $F_{\mathrm{MNE}}<F_{\mathrm{NE}}{ }^{8}$ By this token, the threat point of an MNE is, ceteris paribus, higher than that of an NE, raising its bargaining power. Note that in our setup the effective (average) tax rates are relevant and not the marginal ones, as fixed costs of relocating suggest a lumpy investment decision of firms. A firm will only relocate to a foreign country if tax savings are high enough to cover the fixed costs. Once a firm decides to relocate, it will do so with all its profits to maximize (worldwide) net profits.

The solution to the Nash bargaining problem is then given by

$$
D_{i}^{\star}=\underset{D_{i}}{\operatorname{argmax}}\left[\left(\tau\left(\pi_{i}-D_{i}\right)\right)^{\alpha}\left((1-\tau) \pi_{i}+\tau D_{i}-\left(1-\mathrm{ETR}_{i}^{\prime}\right) \pi_{i}+F_{i}\right)^{1-\alpha}\right] .
$$

The term $\left((1-\tau) \pi_{i}+\tau D_{i}-\left(1-\mathrm{ETR}_{i}^{\prime}\right) \pi_{i}+F_{i}\right)$ actually reflects the investment decision and optimization problem of the firm. Assuming that gross profits are the same in both countries and that the foreign effective tax rate is lower than the French statutory tax rate, $\operatorname{ETR}_{i}^{\prime}<\tau$, all that prevents a firm to relocate are the fixed costs, $F_{i}$, and possible deductions granted by French tax authorities, $D_{i}$. Without any deductions firms, with profits above a certain threshold would relocate, while low-profit firms would remain in France. Setting $D_{i}>0$ can mitigate differences between the foreign effective tax rate and the French statutory tax rate, but does not imply that effective marginal tax rates equalize in both countries as long as fixed costs are strictly positive.

Under the present assumptions, Equation (3) simplifies to

$$
D_{i}^{\star}=\left(1-\alpha \frac{\mathrm{ETR}_{i}^{\prime}}{\tau}\right) \pi_{i}-\frac{\alpha}{\tau} F_{i}
$$

Firm $i$ 's ETR in the domestic country (where it bargains with tax authorities) is thus given by

$$
\operatorname{ETR}_{i}=\frac{\tau\left(\pi_{i}-D_{i}^{\star}\right)}{\pi_{i}}=\alpha\left(\operatorname{ETR}_{i}^{\prime}+\frac{F_{i}}{\pi_{i}}\right)
$$

Obviously, the $\mathrm{ETR}_{i}$ increases with the bargaining power of the government, $\alpha$, and the foreign effective tax rate, $\mathrm{ETR}_{i}^{\prime}$. The $\mathrm{ETR}_{i}$ decreases with pre-tax profits, $\pi_{i}$, and is therefore regressive. This regressivity arises from the opportunity costs of the government. As pre-tax profits rise, domestic tax revenues increase, while the outside option - no tax revenues from firm $i$ at all - becomes increasingly unattractive. Thus, the government is willing to grant more tax deductions to a highly profitable firm in order to ensure that it does not relocate. On the other hand, the $\mathrm{ETR}_{i}$ also increases with the fixed costs of relocating, $F_{i}$. Higher fixed costs reduce a firm's ability to credibly threaten relocation as well as its ability to extract higher tax deductions. We therefore posit the following:

\section{Proposition}

(i) The effective profit tax schedule of firms is downward sloping with their pre-tax profits, i.e., the ETR is regressive. (ii) A firm's ETR increases with the fixed costs of relocating. If $F_{M N E}<F_{N E}$, MNEs face lower ETRs than NEs with the same level of pre-tax profits in equilibrium. (iii) The

${ }^{8}$ While MNEs do already have at least one foreign production site in place, NEs would need to setup one from scratch. We assume that the latter requires higher investment costs than expanding operations at an existing production site. Moreover, MNEs already have knowledge about the foreign country, e.g., its legal environment, local suppliers, etc., which could be an additional source of lower fixed relocation costs in comparison to NEs. 
ETR of a firm increases with the foreign (effective) tax rate. (iv) The ETR schedule is less regressive when the fixed costs of relocation are higher.

The effect in (iv) can be obtained by taking the cross-derivative of Equation (5) with respect to profits, $\pi_{i}$, and fixed costs, $F_{i}$. Graphically speaking, the ETR schedules of MNEs and NEs are both downward sloping. However, with $F_{\mathrm{MNE}}<F_{\mathrm{NE}}$, the ETR schedule of NEs is above the one of MNEs, but MNEs' ETR slope is steeper (more negative). While the ETR schedule is downward sloping due to the size effect and is thereby independent of MNE status, the difference in slope and intercept of the ETR schedule can be explained by the greater footlooseness of MNEs.

In Section A of the online appendix we provide and derive four model extensions. First, we allow for tax competition between the domestic country and a generic foreign country. Second, we alter the government objective function to account for the government's trade-off between tax revenue maximization and employment maximization in the domestic country. Third, we use a constrained Nash bargaining setting in which the government considers the negative effects of high taxes on profits, and thereby employment, in a firm. Lastly, we provide a counterfactual model that omits tax bargaining. In all four modeling approaches points (i) to (iii) of the above-mentioned proposition hold and the functional form of the ETR schedule is very similar.

\section{Empirical analysis}

This section is devoted to assessing and quantifying some of the core insights from the stylized model above based on firm-level data. We do so in two parts. First, we demonstrate that some of the key model predictions are consistent with simple correlations found in the data. Second, we establish a causal relationship between MNE status and the effects of size and footlooseness on MNEs' ETRs, above and beyond the effects of profit shifting.

The stylized model does not include profit shifting activities or illegal tax evasion (to the extent that pre-tax profits do not depend on statutory tax rates and deductions). Hence, any gap in ETRs between MNEs and NEs is assumed to solely accrue to bargaining between tax authorities and firms. This is not generally the case in the data. In the empirical framework we must control for profit shifting activities, such as debt shifting, royalty payments, and transfer pricing, in order to not mis-ascribe the difference in ETRs between MNEs and NEs to bargaining. Only the residual or conditional difference in ETRs (above and beyond profit shifting) between MNEs and NEs can and will be attributed to the bargaining of high-profit firms relative to low-profit firms in general and of mobile MNEs relative to less mobile NEs in particular. We will demonstrate later that this remaining difference can be attributed to firm size independent of MNE status and the greater footlooseness of MNEs relative to identical NEs given their declared profits and must not necessarily be due to evasion.

In what follows, it is useful to distinguish between an entity - i.e., an independent unit of operation within a firm (such as an affiliate or the headquarters) - and a firm. The latter is the conglomerate of all affiliates and the headquarters, while the former is an individual component of that very conglomerate. 


\subsection{Data description}

Data that would permit an assessment of bargaining above and beyond profit shifting on MNEs' relative to NEs' ETRs must contain information on firms' MNE status, profits, tax payments, and observable variables that capture profit shifting (such as information on debt levels, trade activities, and intangibles). Large collections of unconsolidated firm- (or, better, entity-) level data such as Bureau van Dijk's ORBIS database provide these ingredients for a limited set of countries - foremost France, parts of south-eastern Europe, and China. Of those countries, France is a prime candidate: it hosts and headquarters a large number of MNEs and NEs, it levies relatively high profit tax rates, and its economic and political institutions are representative of an industrial economy, including the use of advance tax rulings. We therefore extract the relevant information on French NEs, French MNEs with entities abroad (foreign affiliates), and foreign MNEs with affiliates in France between the years 2007 and 2012. For the sake of better comparability of French NEs with MNEs in the sample, we only include NEs with at least two entities. Every firm in the estimation sample is thus a multi-entity enterprise. ${ }^{9}$ We define MNEs as having at least one independent operational unit in a country other than France where the respective ownership share exceeds $50 \%$.

We only use firms with unconsolidated accounts, which allows us to calculate firms' local profit tax payments and their respective ETRs. We compute the ETR from the ratio of total local profit tax payments (which in France only includes corporate profit taxes) over local pre-tax profits (which in France account for operating and financial profits/losses). We clean the data by deleting firms with abnormal returns, negative revenues, and data errors showing excessive ETRs outside the interval of $[0 \%, 100 \%]$. Moreover, we restrict the sample to firms with (i) profit tax payments of at least $€ 763,000$ and (ii) operating revenues that do not exceed $€ 250$ million. The first restriction ensures that all firms in the sample are subject to the $3.3 \%$ social contribution surtax, while the second restriction ensures that firms in the sample are not subject to the $5 \%$ surtax added after 2011 (raised to $10.7 \%$ after 2014). The applicable statutory tax rate between 2007 and 2012 is thus $34.43 \%$ for all firms in the data. Restricting our sample in this way has two advantages. First, having the same statutory tax rate for all firms eliminates a confounding factor. Second, excluding very big firms, mainly MNEs, makes the two samples of MNEs and NEs in the data more comparable. Only a small share of the firms in our sample are classified as small and medium sized entities by the French government. ${ }^{10}$ Most of the firms we consider are larger firms from the perspective of the French government and we have reason to believe that these firms are able to negotiate tax deductions. Moreover, we are interested in heterogeneous effects due to size differences of firms, thus not focusing exclusively on very large firms helps us to identify the bargaining channel. ${ }^{11}$

Table 1: Entities in France by type

\begin{tabular}{l|rrr}
\hline & Entities & Obs. & Percent \\
\hline Domestic multi-entity & 1,758 & 3,246 & 69.64 \\
Multinational & 632 & 1,415 & 30.36 \\
\hline Total & 2,390 & 4,661 & \\
\hline
\end{tabular}

\footnotetext{
${ }^{9}$ The results below, however, are insensitive to the inclusion of single-entity NEs.

${ }^{10}$ Small and medium sized firms are defined by a total revenues below $€ 50$ million and less than 200 employees.

${ }^{11}$ We do not differentiated manufacturing and service firms and neither excluded public private partnerships from our sample. Our final sample only includes 39 entity-year observations with a service sector Nace Rev. 2 classification. 437 entityyear observations in the unconstrained sample. Only 6 firm-year observations can be classified as public-private-partnerships (PPPs). The model is robust to the exclusion of service firms and PPPs.
} 
Imposing these restrictions yields a sample of 2,390 entities (4,661 entity-year observations) located in France. 632 of these entities $(1,415$, or $30.36 \%$ of the entity-year observations) are MNEs. Table 1 reports the composition of the sample and Table 2 summarizes the entities' observable characteristics. Of the $632 \mathrm{MNE}$ entities in France, 289 are the French subsidiaries of foreign owners, 273 are the French owners of foreign subsidiaries, and 70 are foreign-owned French subsidiaries which themselves own foreign subsidiaries. For this last category of entities, the host country of the foreign owner of the French entity always charges a higher tax rate than the lowest-tax host country of the foreign subsidiary of the same French entity in the data.

Table 2: Summary STATISTICS

\begin{tabular}{l|crrrr}
\hline Variable & Firm-year obs. & Mean & Std. dev. & Minimum & Maximum \\
\hline ETR (\%) & 4,661 & 31.29 & 9.64 & 1.19 & 99.97 \\
Profit pre-tax (€mn.) & 4,661 & 8.27 & 9.13 & 0.88 & 102.67 \\
Profit post-tax (€mn.) & 4,661 & 5.73 & 7.29 & 0.00 & 76.13 \\
Tax payments (€mn.) & 4,661 & 2.26 & 2.37 & 0.76 & 26.54 \\
Revenue (€mn.) & 4,661 & 75.53 & 55.96 & 0.26 & 249.52 \\
Productivity & 4,661 & 0.77 & 1.10 & 0.04 & 59.00 \\
Workers & 4,661 & 248.12 & 711.68 & 1 & 43,300 \\
Labor costs (€mn.) & 4,661 & 12.64 & 13.55 & 0.03 & 134.28 \\
Capital (€mn.) & 4,661 & 8.35 & 27.23 & 0.00 & 793.08 \\
Debt (€mn.) & 4,661 & 3.09 & 16.16 & 0.00 & 400.18 \\
Export revenue (€mn.) & 4,661 & 20.23 & 33.29 & 0.00 & 272.40 \\
Intangibles (€mn.) & 4,661 & 4.30 & 17.61 & 0.00 & 395.62 \\
\hline Variable & Country-year obs. & Mean & Std. dev. & Minimum & Maximum \\
\hline Foreign EATR (\%) & 307 & 24.15 & 7.18 & 0.00 & 38.73 \\
Foreign population ('000s) & 307 & 89,300 & 245,000 & 311.57 & $1,350,000$ \\
Foreign GDP per capita (constant USD) & 307 & $22,893.48$ & $15,320.27$ & 744.42 & $74,021.46$ \\
\hline
\end{tabular}

Foreign affiliate or owner hosts: Angola, Australia, Austria, Belgium, Bosnia and Herzegovina, Brazil, Bulgaria, Cameroon, Canada, Chile, China, Colombia, Congo, Cote d'Ivoire, Cyprus, Czech Republic, Denmark, Egypt, Estonia, Finland, Gabon, Germany, Ghana, Greece, Guinea, Hong Kong, Hungary, Iceland, India, Indonesia, Ireland, Israel, Italy, Japan, Kenya, Latvia, Lithuania, Luxembourg, Madagascar, Malaysia, Mauritius, Mexico, Morocco, Mozambique, Netherlands, New Zealand, Norway, Panama, Peru, Poland, Portugal, Qatar, Russian Federation, Saudi Arabia, Senegal, Serbia, Singapore, Slovakia, South Africa, South Korea, Spain, Sweden, Switzerland, Thailand, Tunisia, Turkey, Ukraine, United Arab Emirates, United Kingdom, United States, Venezuela, and Viet Nam.

The upper part of Table 2 summarizes the entity-level variables pertaining to all sample entities located in France. According to the table, the average ETR is $31.29 \%$ for all entities in the sample.

We use the procedure of Levinsohn and Petrin (2003) and Petrin et al. (2004) to estimate firm-level productivity in order to control for the correlation between unobservable productivity shocks and input levels. ${ }^{12}$ Note that total revenues and productivity using the procedure of Levinsohn and Petrin (2003) and Petrin et al. (2004) shown in Table 2 are very dispersed, indicating a large degree of heterogeneity in size as well as productivity across the firms in our sample. For robustness, we repeat the analysis using (i) a Solow-residualtype total factor productivity and (ii) estimates based on the procedure of Olley and Pakes (1996). The presentation of these results is relegated to Section B of the online appendix. However, the main findings

\footnotetext{
${ }^{12}$ Specifically, we estimate a log-linear production function of the following form

$$
y_{i t}=\varsigma_{0}+\varsigma_{l} l_{i t}+\varsigma_{k} k_{i t}+\varsigma_{m} m_{i t}+\chi_{i t}+o_{i t},
$$

where $y_{i t}, l_{i t}, k_{i t}$, and $m_{i t}$ are the firm's gross revenues, employed labor, capital, and material costs of firm $i$ at time $t$ in logs, respectively. The remainder term consists of a transmitted productivity term $\chi_{i t}=\chi_{i t}\left(k_{i t}, m_{i t}\right)$ that follows a first-order Markov process (known to the firm) and a term that is uncorrelated with the input choice, $o_{i t}$. Using the interaction of capital and material costs as a proxy for the unobservable productivity term allows to identify the productivity level.
} 
are not sensitive to the choice of productivity estimation.

In the lower part of Table 2, we present statistics on the effective average tax rate (EATR) on foreign corporate profits, ${ }^{13}$ and foreign country-size measures of population and real per-capita income from the World Bank's World Development Indicators for those foreign countries in which the multinational entities in the sample either have foreign affiliates or foreign owners. Overall, the aforementioned 1,415 entity-year MNE observations are nested in 307 country-year observations involving 72 countries. In the case of multiple foreign affiliates (entities) per firm, we use country-level data for the lowest-taxing foreign location. ${ }^{14}$

\subsection{Stylized correlations}

The stylized model in Section 3 predicts corporate tax systems to be regressive, whereby firms with higher profits face lower ETRs, irrespective of the entity type. In order to gain preliminary insights into this relationship, we estimate a simple regression of ETR as the dependent variable on log pre-tax profits, $\ln \left(\pi_{i t}\right)$, log pre-tax profits squared, $\ln \left(\pi_{i t}\right)^{2}$, and cubic log pre-tax profits, $\ln \left(\pi_{i t}\right)^{3}$, for all 4,661 entity-year observations as well as for observations pertaining to NEs and MNEs separately. Specifically, we estimate:

$$
\mathrm{ETR}_{i t}=\sum_{z=1}^{3} \gamma_{z} \ln \left(\pi_{i t}\right)^{z}+\kappa+\Xi_{i t}+\eta_{i t}
$$

where $\mathrm{ETR}_{i t}$ is the effective (average) tax rate of an entity $i$ located in France at time $t, \gamma_{z}$ are regression parameters of interest, $\Xi_{i t}$ is a collection of year and firm fixed effects at time $t, \kappa$ is a constant, and $\eta_{i t}$ is an error term. The parameter estimates can be found in Table 3. Most importantly, the associated predictions are plotted for the average firm and year in Figure 2, the inspection of which is key as log before-tax profits enter cubically in the econometric model.

According to Table 3 and Figure 2, the estimation results suggest the following insights. ${ }^{15}$ First, the ETR declines with log pre-tax profits such that the applied ETR is generally regressive for both types of firms. Second, the MNEs' ETR schedule is situated below the NEs' ETR schedule. Third, the ETR schedule of MNEs has a steeper slope and is thus more regressive over most of the range of pre-tax profits we consider in our sample. The (OLS-based) results from this simple empirical exercise are in line with the hypotheses of the stylized model summarized by the proposition in Section 3.

\footnotetext{
${ }^{13}$ In contrast to statutory rates, EATRs account for deductions, credits, and other adjustments available to firms and is therefore a relatively close approximation of the lowest-taxed affiliate's ETR. The respective data are taken from Boesenberg and Egger (2016) and Boesenberg et al. (2018), which apply the Devereux and Griffith $(1998,2003)$ model.

${ }^{14}$ Egger et al. (2018) show that most multi-entity firms have only one affiliate entity. Since we bound our sample both from above in terms of pre-tax profits and from below in terms of taxes paid, our sample does not include superstar MNEs and the majority of firms in our sample are likely to be single-foreign-entity firms by construction and would not be affected the selection of its lowest-taxing foreign location.

${ }^{15}$ We use the variation of profits and ETR within a firm over time to estimate the ETR schedule. It should be noted that the data at hand vary both across firms as well as time. The relative importance of the across-firm variation is largely dominant (with more then $99 \%$ of the overall model variation being contributed by the firm fixed effects) in the data underlying the estimates of Equation (6).
} 
Table 3: OLS: Estimation of the French ETR sChedule

\begin{tabular}{|c|c|c|c|}
\hline Variable & $\begin{array}{l}\text { All obs. } \\
\text { (1) }\end{array}$ & $\begin{array}{l}\text { NE obs. } \\
(2)\end{array}$ & $\begin{array}{l}\text { MNE obs. } \\
\text { (3) }\end{array}$ \\
\hline $\ln \left(\pi_{i t}\right) \quad\left(\gamma_{1}\right)$ & $\begin{array}{c}-62.64^{* * *} \\
(3.64)\end{array}$ & $\begin{array}{c}-65.45^{* * *} \\
(4.17)\end{array}$ & $\begin{array}{c}-63.28^{* * *} \\
(7.11)\end{array}$ \\
\hline $\ln \left(\pi_{i t}\right)^{2} \quad\left(\gamma_{2}\right)$ & $\begin{array}{l}27.34^{* * *} \\
(1.96)\end{array}$ & $\begin{array}{l}30.08^{* * *} \\
(2.32)\end{array}$ & $\begin{array}{l}24.42^{* * *} \\
(3.70)\end{array}$ \\
\hline $\ln \left(\pi_{i t}\right)^{3} \quad\left(\gamma_{3}\right)$ & $\begin{array}{c}-3.97^{* * *} \\
(0.33)\end{array}$ & $\begin{array}{c}-4.44^{* * *} \\
(0.40)\end{array}$ & $\begin{array}{c}-3.26^{* * *} \\
(0.59)\end{array}$ \\
\hline Constant $(v)$ & $\begin{array}{l}71.99^{* * *} \\
(3.70)\end{array}$ & $\begin{array}{l}83.27^{* * *} \\
(5.28)\end{array}$ & $\begin{array}{l}76.26^{\text {*** }} \\
(5.58)\end{array}$ \\
\hline$R^{2}$ & 0.80 & 0.85 & 0.78 \\
\hline Observations & 4,661 & 3,246 & 1,415 \\
\hline
\end{tabular}

Pre-tax profits in $€ m n$. Year and firm fixed effects are included. Standard errors in parentheses. ***, **, and

* indicate levels of statistical significance at 1, 5, and 10 percent, respectively.

Moreover, we can use Figure 2 to visualize the two bargaining effects of being an MNE on the ETR. A movement along the NEs' ETR schedule (from point A to B) corresponds to the size effect, higher profits due to the MNE status translate to a lower ETR given the regressivity of the ETR schedule. Switching from the NEs' ETR schedule to the MNEs' ETR schedule (from point B to C) gives us the footlooseness effect of being an MNE. The the vertical distance (in terms of the expected ETR) between points A to C is the overall effect, which can be decomposed into the size and the footlooseness effect. ${ }^{16}$

Predicted ETR for MNEs and NEs

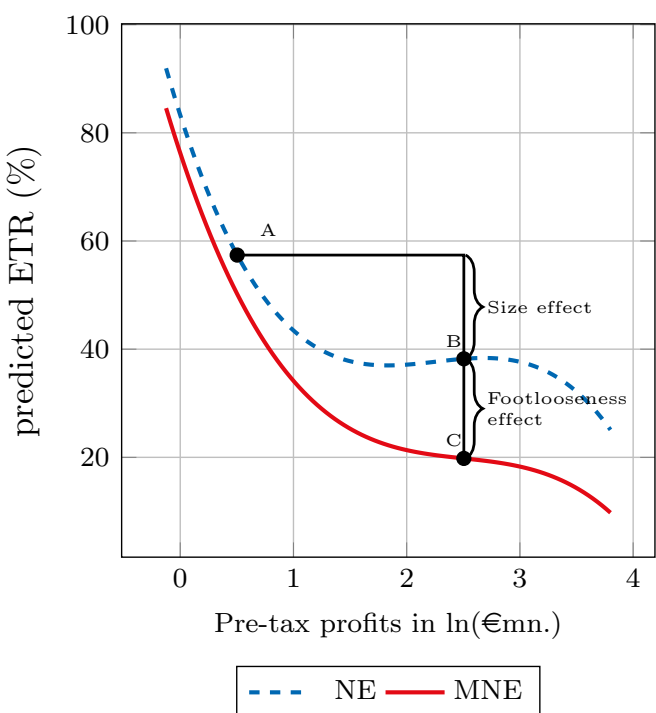

Figure 2: Predicted ETR schedule Based On OLS

Next, we focus on a theory-guided estimation of the determinants of the ETR based on Equation (5). Specifically we emphasize the role of fixed costs, $F_{i}$. In doing so, we focus entirely on MNEs - either

\footnotetext{
${ }^{16}$ Note that the gap between MNE's and NE's ETR tax schedule in general increases, we take this as evidence that bargaining is an important factor and the lower ETR of MNEs does not arise from selection effects. We formalize this argument based on the fourth stylized model in Section A of the online appendix.
} 
ones whose parent firms are located in France or ones whose parent firms are located abroad with at least one affiliate in France. Following the aforementioned proposition, the ETR of a French MNE entity should increase with the foreign (effective) tax rate, according to Equation (5), at any level of fixed costs of relocating. In addressing the role of foreign (effective) profit tax rates on the ETR, we amend the specification in Equation (6) by including the foreign effective tax rate of the country in which the French entity has an affiliate. Because we cannot precisely estimate the foreign effective tax rate, $\mathrm{ETR}_{i t}^{\prime}$, of the affiliated entities of firm $i$, we use the effective average tax rate in the foreign country, $\operatorname{EATR}_{i t}^{\prime}$ as a proxy. The latter is, however, a good measure of effective foreign taxation a firm could expect after relocating. For these tax rates, we use the lowest EATR within the foreign network of each MNE to measure EATR ${ }_{i t}^{\prime}$ and estimate the following equation:

$$
\operatorname{ETR}_{i t}=\sum_{z=1}^{3} \beta_{z} \ln \left(\pi_{i t}\right)^{z}+\varphi \mathrm{EATR}_{i t}^{\prime}+\Gamma_{i t}+\epsilon_{i t}
$$

where $E T R_{i t}$ is the effective tax rate of a French entity $i$ at time $t$, and $\ln \left(\pi_{i t}\right)$ are the log pre-tax profits of this entity. $\Gamma_{i t}$ contains a collection of fixed effects in the dimension of years, foreign-lowest-tax-country in $i$ 's MNE network at time $t$, and the main sector affiliation of $i$ at time $t$, and $\epsilon_{i t}$ is an error term. As there is very little variation in the foreign EATR or the affiliate structure of firms over time, we cannot include firm fixed effects and instead resort to sector-fixed effects to identify the impact of the foreign EATR on the firm's ETR.

In the estimation, we restrict our sample to MNEs, where the foreign (effective average) tax rate is observable. We also distinguish between foreign-owned entities (designated foreign parents), which includes all foreignowned entities in France, irrespective of whether they themselves hold foreign entities or not, and foreignaffiliate-owning French entities (designated French parents), which includes all French entities that own affiliates abroad, irrespective of whether the French entities are headquarters or are themselves foreignowned. Hence, there is some small overlap in the samples. ${ }^{17}$ Overall, we suspect that the costs of relocating a headquarters are higher than those of relocating any other entity. Thus, the ETR schedule should be more regressive for the former, while for both subgroups a higher foreign effective tax rate would increase an MNE entity's ETR in France.

Table 4 summarizes the key regression results corresponding to Equation (7). Column (1) presents the result for all MNE entities located in France in our sample. Considering the distribution of $\ln \left(\pi_{i t}\right)$ in conjunction with the coefficient estimates $\left(\widehat{\beta}_{z}\right)$, higher pre-tax profits reduce a firm's ETR as before, which squares with the insights of the theoretical model discussed above. Notice that the estimates $\widehat{\beta}_{z}$ are not statistically different from their counterparts $\widehat{\gamma}_{z}$ in Table 3. A higher foreign tax rate is expected to raise a firm's French ETR. The foreign EATR clearly increases the ETR of French entities with foreign parents, see Column (2). In general, the effect of foreign tax rates is stronger for French entities that are owned by foreign MNEs than for French parent entities, where the effect is not significant, see Column (3). Implicitly, this means that foreign-owned affiliates in France are gaining more from bargaining and, in the context of the theoretical model, the bargaining power, $\alpha$, of foreign owned affiliates is higher than that of French-owned entities or reallocation costs are lower. We undertake a similar analysis using foreign statutory tax rates, and the associated results confirm the assumption that effective tax rates are the relevant indicator of foreign taxation over statutory tax rates. ${ }^{18}$ Furthermore, we test the assumption that the coefficient on $\mathrm{EATR}_{i t}^{\prime}$ in

\footnotetext{
${ }^{17}$ For that reason, the number of observations in Columns (2) and (3) add to slightly more than the one in Column (1) of Table 4.

${ }^{18}$ Statutory tax rates are only somewhat significant in similar regressions.
} 
Table 4: EFFECT OF FOREIGN TAXES ON A FIRM's ETR BY OWNERShiP STRUCTURE

\begin{tabular}{lc|ccc}
\hline \multicolumn{2}{c|}{ Variable } & All MNEs & Foreign parents & French parents \\
& & $(1)$ & $(2)$ & $(3)$ \\
\hline $\ln \left(\pi_{i t}\right)$ & $\left(\beta_{1}\right)$ & $-54.87^{* * *}$ & $-57.59^{* * *}$ & $-42.57^{* * *}$ \\
& & $(7.86)$ & $(11.08)$ & $(7.99)$ \\
$\ln \left(\pi_{i t}\right)^{2}$ & $\left(\beta_{2}\right)$ & $21.77^{* * *}$ & $23.07^{* * *}$ & $15.64^{* * *}$ \\
& & $(3.70)$ & $(5.32)$ & $(3.87)$ \\
$\ln \left(\pi_{i t}\right)^{3}$ & $\left(\beta_{3}\right)$ & $-2.81^{* * *}$ & $-2.96^{* * *}$ & $-1.93^{* * *}$ \\
& & $(0.54)$ & $(0.80)$ & $(0.57)$ \\
EATR $_{i t}^{\prime}$ & $(\varphi)$ & $0.32^{* *}$ & $0.30^{* *}$ & 0.14 \\
& & $(0.16)$ & $(0.15)$ & $(0.22)$ \\
Constant & $(v)$ & $69.81^{* * *}$ & $65.46^{* * *}$ & $63.08^{* * *}$ \\
& & $(5.44)$ & $(9.16)$ & $(5.42)$ \\
\hline \multirow{2}{*}{$R^{2}$} & & 0.32 & 0.31 & 0.32 \\
Observations & 1,415 & 612 & 985 \\
\hline
\end{tabular}

Only those foreign markets with an affliate with the lowest foreign EATR' are considered. The sample for foreign headquarters uses French MNE units which are headquartered abroad, irrespective of whether they hold foreign affiliates themselves or not. The sample for French parents uses French MNE units which hold affiliates abroad, irrespective of whether they themselves are headquartered in France or abroad. Hence, there is some overlap between these samples. Standard errors in parentheses clustered at firm level. We suppress estimates of the lowest-tax-country-in-i's-network, time-, and sector-fixed effects. ***, **, and * indicate levels of statistical significance at 1, 5, and 10 percent, respectively.

Column (2) is higher than and significantly different from the coefficient on $\operatorname{EATR}_{i t}^{\prime}$ in Column (3). To that end, we run the following two models using $\rho_{i t}$ to denote the error term:

$$
\begin{aligned}
\operatorname{ETR}_{i t}=\sum_{z}^{3}\left(\varrho_{z} \ln \left(\pi_{i t}\right)^{z}+\phi_{z}\left(\text { ForeignParent }_{i t} \times \ln \left(\pi_{i t}\right)^{z}\right)\right) \\
+\psi \mathrm{EATR}_{i t}^{\prime}+\varpi\left(\text { ForeignParent }_{i t} \times \mathrm{EATR}_{i t}^{\prime}\right)+\rho_{i t},
\end{aligned}
$$

where the test on joint significance of $\phi_{z}$ and $\varpi$ results in an F-statistic of 3.13, which is significant at the $95 \%$ level, while the one-sided t-test for $\varpi$ is not significant. ${ }^{19}$ Additionally, we run the following regression:

$$
E T R_{i t}=\sum_{z}^{3} \varrho_{z} \ln \left(\pi_{i t}\right)^{z}+\psi \mathrm{EATR}_{i t}^{\prime}+\varpi\left(\text { ForeignParent }_{i t} \times \mathrm{EATR}_{i t}^{\prime}\right)+\rho_{i t},
$$

where we force the coefficient $\varrho_{z}$ to be the same for foreign-owned and French-owned firms, which results in a significant coefficient for $\varpi$ of -0.04 with a standard error of 0.02 .

\subsection{Entropy balancing to establish causal relationships}

Even though we can measure firms' profits in France and estimate the shape of the nexus of profits and the ETR, we cannot straightforwardly compare MNEs and NEs in terms of profits and the associated ETR to gauge the bargaining component in ETRs, since MNEs can manipulate their profits in a way that is beyond

\footnotetext{
${ }^{19}$ Compared to Equation (6), the cross-main-sector variation in Equation (8) is less important in the underlying data, with only about $75 \%$ of the variation contributed by main-sector fixed effects.
} 
the reach of NEs. This leads to an endogeneity of profits, $\ln \left(\pi_{i t}\right)$, in the above estimations. We address this by using entropy balancing, which is a generalized weighting procedure. In doing so, we allow profits and MNE status to be simultaneously determined by a set of observables.

Being an MNE affects the tax rate in two ways. (i) All else equal (meaning in the absence of or beyond profit shifting), MNEs have higher profits on average (see Helpman et al., 2004), which mechanically reduces their effective tax rate if the ETR schedule is regressive. (ii) MNEs are in a better bargaining position relative to NEs and can thus reduce their tax burden even further. The first, the size effect, is related to the better bargaining position of larger firms, while the latter, the footlooseness effect, arises from the reduced perceived or expected costs of MNEs to relocate. Thus, we first need to estimate profits that are free of profit shifting aspects to arrive at comparable units between NEs and MNEs. For this, we use a procedure capable of retrieving the average difference between NEs and MNEs in terms of their (log) profits after conditioning on a broad set of controls, including variables that are typically indicative of profit shifting, i.e., export volumes, debt, and intangible assets. The remaining control variables are joint determinants of (revealed) profitability and MNE status such that the obtained conditional mean is characterized by the same targeted moments of the distribution of each and every such joint determinant between MNEs and NEs.

We apply entropy balancing as proposed by Hainmueller (2012) and Hainmueller and Xu (2013). Akin to other approaches invoking a selection (into treatment; here, MNE status) on observables which jointly determine treatment status as well as outcome (in this case, (log) pre-tax profits or the French ETR), entropy balancing lends itself to a weighting regression framework. With traditional approaches (such as linear regression or propensity score matching), the weights are obtained in a way that is unconditional on the distribution of the observables between the treated and the untreated. This is true for linear regression, where all weights are identical, as well as for propensity score matching, which is analogous to an inverse propensity-scoreweighting regression (see Wooldridge, 2007). Differences in the covariate distributions between the treated and the untreated observations may confound any identification of the parametric or nonparametric link between treatment status and outcome. Entropy balancing avoids this problem by determining the weights subject to constraints which enforce the balancing of targeted moments of the distribution of observables captured by the respective entropy in the covariates - between the samples of MNE and NE data points.

Specifically, we are interested in the average treatment effect on the treated (ATT) - the effect of being an MNE on the MNEs in the data. After subsuming all observables into the vector $X_{i t}$, we can drop entity-time indices it and write the ATT as

$$
\mathrm{ATT}=E[E T R \mid M N E=1]-\int E[E T R \mid X=x, M N E=1] f_{X \mid M N E=1}(x) d x,
$$

wherein ETR denotes the ETR outcome associated with MNE status, $M N E$, and $X$ are the observable joint determinants of MNE status and the ETR. The ATT is identified by selecting on a range of observables, such that the ETR is independent of the MNE treatment status given the observables. This holds as long as there is some overlap between the treated and the untreated in the values that the observables $(x)$ may take within the support of the observables among the treated, $f_{X \mid M N E=1}$. In order to estimate this last term, the covariate distribution of the control group's observables must be adjusted to match the covariate distribution of the treated. This enforces the orthogonality of the treatment indicator, $M N E$, and the observables which is required for a causal inference of the treatment effect (see Hainmueller and $\mathrm{Xu}, 2013$ ). Moreover, this procedure automatically closes the gap between the ATT and the average treatment effect 
(ATE), which is not the case when the balancing of the distribution of observables is not enforced. In drawing a random entity from the data of MNEs and NEs, the predicted effect of being an MNE relative to being an NE on either outcome (profits or the ETR) is the same under entropy balancing regression but not under a propensity score weighting regression, which does not constrain the distribution of the observables to be the same between treated and untreated units. Accordingly, entropy balancing generalizes the unconstrained weighting approaches of treatment effects under a selection on observables, including propensity score matching. Relative to unconstrained weighting approaches, entropy balancing gives greater weight to observations in the control group that are similar to observations in the treatment group in terms of the observables.

In the subsequent analysis, we denote the weight (of an entity $i$ in year $t$ ) generated through entropy balancing by $\lambda_{i t}$. Table 5 summarizes the targeted (balanced) moments of the observables in the determination of the balancing weights $\lambda_{i t}$.

Table 5: Targeted moments of observable variables in the entropy Balancing of MNEs $\left(\lambda_{i t}\right)$

\begin{tabular}{l|ccc}
\hline & \multicolumn{3}{|c}{ Targeted moment } \\
Control & Mean & Variance & Skewness \\
\hline $\ln ($ Revenues $)$ & YES & YES & YES \\
$\ln ($ Productivity $)$ & YES & YES & YES \\
$\ln ($ Employees $)$ & YES & YES & NO \\
$\ln ($ Capital $)$ & YES & YES & NO \\
$\ln ($ Labor costs $)$ & YES & YES & NO \\
$\ln \left(\frac{\text { Exports }}{\text { Revenues }}\right)$ & YES & YES & NO \\
$\ln \left(\frac{\text { Debt }}{\text { Revenues }}\right)$ & YES & YES & NO \\
$\ln \left(\frac{\text { Intangibles }}{\text { Revenues }}\right)$ & YES & YES & NO \\
Mundlak-type means & YES & YES & YES \\
$\ln ($ Revenues $) \times \ln ($ Productivity $)$ & YES & YES & NO \\
$\ln ($ Revenues $) \times \ln ($ Employees $)$ & YES & YES & NO \\
$\ln ($ Revenues $) \times \ln ($ Capital $)$ & YES & YES & NO \\
Time-fixed effects & YES & NO & NO \\
\hline
\end{tabular}

While we would ideally balance on direct measures of actual profit shifting, e.g., internal debt payments, internal royalty payments ( $R \& D$ expenditures), or internal pricing of exports and imports, these data are not available for French firms in the ORBIS database. We thus turn to examples from the literature on profit shifting (see Egger et al., 2014; Lassmann and Zoller-Rydzek, 2018; among others) for the best proxy measures - we use $\ln \left(\frac{\text { Exports }}{\text { Revenues }}\right), \ln \left(\frac{\text { Debt }}{\text { Revenues }}\right)$, and $\ln \left(\frac{\text { Intangibles }}{\text { Revenues }}\right)$ to approximate firms' profit shifting in our sample. In order to determine if profit-shifting is happening, tax authorities and accounting firms take these variables from the ORBIS database in order to identify abnormally high or abnormally low pre-tax profits. Thus, these variables are very indicative of profit shifting activities. During auditing procedures, tax authorities and firms' tax accountants generally argue about the appropriate comparison (what we would consider the correct construction of the control groups) with respect to pre-tax profits, revenues, exports, debt, and intangible assets; see Escaut et al. (2012).

In addition to the entity-level variables, the interactions thereof, and time-fixed effects in Table 5, we balance on three moments of the entity-specific variable means (see Mundlak, 1978) of $\ln$ (Revenues), $\ln$ (Productivity), $\ln ($ Employees $), \ln ($ Capital $), \ln ($ Labor costs $), \ln \left(\frac{\text { Exports }}{\text { Revenues }}\right), \ln \left(\frac{\text { Debt }}{\text { Revenues }}\right)$, and $\ln \left(\frac{\text { Intangibles }}{\text { Revenues }}\right)$. However, the 
entropy-weighted means are highly collinear with the remaining balancing variables and thus do not matter.

\subsection{Determining the ETR effect of being an MNE}

To apply entropy balancing as described in the previous subsection, we target the entity and firm fundamentals and moments listed in Table 5 and obtain the balancing statistics presented in Table 6 . The table reports the moments of interest of the main observables and is organized in three horizontal blocks: the first one focuses on the control units (i.e., NEs) before balancing the observables; the second block reports the same moments among the treated units (i.e., MNEs); and the third block summarizes the moments of the control units after balancing. In comparing the first with the second and third horizontal block in the table, we see that some of the moments of the main variables differ significantly between MNEs and NEs prior to balancing. However, this difference vanishes after balancing. ${ }^{20}$ In particular, the covariate balancing vastly improves the comparability of the higher moments in the data.

Table 6: Balanced: French MNEs and domestic multi-entity firms

\begin{tabular}{l|ccc|ccc|ccc}
\hline & \multicolumn{3}{|c|}{ Control } & \multicolumn{3}{c|}{ Treatment } & \multicolumn{3}{c}{ Balanced Control } \\
& Mean & Variance Skewness & Mean & Variance & Skewness & Mean & Variance Skewness \\
\hline $\ln ($ Revenues $)$ & 17.81 & 0.679 & -0.4084 & 17.93 & 0.639 & -0.9671 & 17.93 & 0.639 & -0.9671 \\
$\ln ($ Productivity $)$ & 6.490 & 0.151 & 1.136 & 6.563 & 0.256 & 2.109 & 6.564 & 0.256 & 2.109 \\
$\ln ($ Employees $)$ & 4.85 & 1.37 & & 4.99 & 1.38 & & 4.99 & 1.38 & \\
$\ln ($ Capital $)$ & 14.42 & 3.03 & 14.97 & 2.76 & & 14.97 & 2.76 & \\
$\ln ($ Labor costs $)$ & 16 & 1.153 & 16 & 1.072 & & 16 & 1.072 & \\
$\ln \left(\frac{\text { Exports }}{\text { Revenues }}\right)$ & 0.225 & 0.082 & 0.359 & 0.087 & & 0.359 & 0.087 & \\
$\ln \left(\frac{\text { Debt }}{\text { Revenuies }}\right)$ & 0.03263 & 0.029 & 0.07544 & 0.199 & & 0.07544 & 0.199 \\
$\ln \left(\frac{\text { ntangibles }}{\text { Revenues }}\right)$ & 0.05729 & 0.056 & 0.07284 & 0.091 & & 0.07284 & 0.091 & \\
\hline
\end{tabular}

Given the balancing summarized above, we use the balancing weights, $\lambda_{i t}$, to obtain an estimate of the ETR schedule considering the endogeneity of $(\log )$ pre-tax profits, $\ln \left(\pi_{i t}\right)$, and the binary MNE status, $\mathrm{MNE}_{i t}$. For this, we weight the outcome variable of interest, $\mathrm{ETR}_{i t}$, $(\log )$ pre-tax profits, and the binary MNE indicator by $\lambda_{i t}$ to obtain $\widetilde{\mathrm{ETR}}_{i t}, \ln \left(\widetilde{\pi}_{i t}\right)$, and $\widetilde{\mathrm{MNE}}_{i t}$, respectively, and estimate the specification below.

\footnotetext{
${ }^{20}$ We are able to balance on different moments with varying degrees of precision. The degree of precision used is indicated by the number of digits reported in Table 6 .
} 
Table 7: Balanced: Estimation of the French ETR schedule

\begin{tabular}{|c|c|c|c|}
\hline \multicolumn{2}{|l|}{ Variable } & $\begin{array}{l}\text { OLS } \\
(1)\end{array}$ & $\begin{array}{c}\text { Entropy } \\
\text { balancing } \\
(2)\end{array}$ \\
\hline $\ln (\widetilde{\pi})$ & $\left(\omega_{1}\right)$ & $\begin{array}{c}-59.73^{* * *} \\
(2.79)\end{array}$ & $\begin{array}{c}-48.65^{* * *} \\
(6.00)\end{array}$ \\
\hline $\ln (\widetilde{\pi})^{2}$ & $\left(\omega_{2}\right)$ & $\begin{array}{l}25.00^{* * *} \\
(1.46)\end{array}$ & $\begin{array}{l}20.52^{* * *} \\
(3.29)\end{array}$ \\
\hline $\ln (\widetilde{\pi})^{3}$ & $\left(\omega_{3}\right)$ & $\begin{array}{c}-3.25^{* * *} \\
(0.23)\end{array}$ & $\begin{array}{c}-2.76^{* * *} \\
(0.56)\end{array}$ \\
\hline$\widehat{\mathrm{MNE}}$ & $(\mu)$ & $\begin{array}{c}-2.59 \\
(3.72)\end{array}$ & $\begin{array}{c}-9.31^{* *} \\
(4.51)\end{array}$ \\
\hline$\widetilde{\mathrm{MNE}} \times \ln (\tilde{\pi})$ & $\left(\vartheta_{1}\right)$ & $\begin{array}{c}9.00 \\
(5.51)\end{array}$ & $\begin{array}{l}15.75^{* *} \\
(7.62)\end{array}$ \\
\hline$\widetilde{\mathrm{MNE}} \times \ln (\widetilde{\pi})^{2}$ & $\left(\vartheta_{2}\right)$ & $\begin{array}{c}-6.22^{* *} \\
(2.54)\end{array}$ & $\begin{array}{c}-8.45^{* *} \\
(3.98)\end{array}$ \\
\hline$\widetilde{\mathrm{MNE}} \times \ln (\widetilde{\pi})^{3}$ & $\left(\vartheta_{3}\right)$ & $\begin{array}{l}0.93^{* *} \\
(0.37)\end{array}$ & $\begin{array}{c}1.23^{*} \\
(0.64)\end{array}$ \\
\hline Constant & $(v)$ & $\begin{array}{l}74.27^{* * *} \\
(1.64)\end{array}$ & $\begin{array}{l}66.25^{* * *} \\
(3.40)\end{array}$ \\
\hline $\begin{array}{l}\text { F-statistic } \\
\text { Observations }\end{array}$ & & $\begin{array}{l}44.45 \\
4,661\end{array}$ & $\begin{array}{l}20.43 \\
4,661\end{array}$ \\
\hline
\end{tabular}

Standard errors in parentheses obtained through bootstrapping. ***, **, and * indicate levels of statistical significance at 1,5 , and 10 percent, respectively. F-statistic is for the joint significance of all MNE effects.

$$
\widetilde{\operatorname{ETR}}_{i t}=v+\sum_{z=1}^{3} \omega_{z} \ln \left(\widetilde{\pi}_{i t}\right)^{z}+\mu \widetilde{\mathrm{MNE}}_{i t}+\sum_{z=1}^{3} \vartheta_{z} \widetilde{\mathrm{MNE}}_{i t} \ln \left(\widetilde{\pi}_{i t}\right)^{z}+\rho_{i t}
$$

where $\omega_{z}$ gives the coefficients of the ETR schedule for NEs and where $\mu$ and $\vartheta_{z}$ are components of the conditional ATT and ATE of MNE status on the ETR beyond profit shifting, i.e., the change of the ETR intersection and slope due to being an MNE, respectively. The parameter $v$ is a constant and $\rho_{i t}$ is an error term. Since we condition on domestic-versus-foreign average tax- and profit-shifting-related differences in the pre-tax profits when estimating $\omega_{z}$ in Equation (11), any remaining ATT (and ATE) of being an MNE on the ETR is attributable to the footlooseness effect of being an MNE.

Otherwise identical firms will only differ in their MNE status. Moreover, by including firm-specific Mundlaktype variable means in the balancing weights, we can compare the results of (11) to the firm-fixed effects regression estimated from Equation (6). In Column (1) of Table 7 we present the estimated coefficients using OLS, while Column (2) shows the estimated coefficients using the balancing weights, $\lambda_{i t}$. The coefficients of this estimation will next be used to quantify the size and footlooseness effect.

To determine the size effect, we need to know the additional profits an MNE is able to generate relative to an NE. We do so by estimating

$$
\ln \left(\widetilde{\pi}_{i t}\right)=\delta \widetilde{\mathrm{MNE}}_{i t}+\iota+\nu_{i t}
$$

where $\delta$ gives the additional profits of being an MNE. Note that analogous to the estimation of Equation 
(11) we can forgo firm-fixed effects in Equation (12) due to the inclusion of firm-specific Mundlak-type means in the entropy balancing. Table 8 shows the estimated additional profits using the balancing weights, $\lambda_{i t}$. Without balancing, the pre-tax profits of MNEs are $46 \%$ higher than those of NEs, while conditioning on entity and firm fundamentals reduces this difference to $20 \%$. The average firm in our sample has about $€ 8.27$ million in pre-tax profits, random assignment of the MNE status under balancing would therefore imply a pre-tax profit increase of about $€ 1.65$ million.

Table 8: The ATE of MNE status on PRofits

\begin{tabular}{c|cc}
\hline Variable & $\begin{array}{c}\text { OLS } \\
(1)\end{array}$ & $\begin{array}{c}\text { Entropy } \\
\text { balancing } \\
(2)\end{array}$ \\
\hline MNE $(\delta)$ & $\begin{array}{c}0.38^{* * *} \\
(0.03)\end{array}$ & $\begin{array}{c}0.18^{* * *} \\
(0.03)\end{array}$ \\
\hline Observations & 4,661 & 4,661 \\
\hline
\end{tabular}

The ATE of MNE status in the balanced regression is the effect beyond profit shifting activities. Standard errors in parentheses obtained through bootstrapping. ***, **, and * indicate levels of statistical significance at 1, 5, and 10 percent, respectively.

We can then translate these additional pre-tax profits into changes of the ETR (size effect) by using the estimated additional (log) pre-tax profits, $\widehat{\delta}$, in conjunction with the estimated parameters from Equation (11). The change of the ETR for a given level of pre-tax profits, $\pi$, can be written as

$$
\Delta \operatorname{ETR}_{i t}\left(\pi_{i t}\right)=\left(\sum_{z=1}^{3} \hat{\omega}_{z} \ln \left(\pi_{i t}\right)^{z}\right)-\left(\sum_{z=1}^{3} \hat{\omega}_{z}\left(\ln \left(\pi_{i t}\right)+\hat{\delta}_{i t}\right)^{z}\right)
$$

where $\hat{\omega}_{z}$ are the estimated coefficients from Equation (11) and $\hat{\delta}$ are the estimated (log) additional profits from Equation (12). Note that we use the ETR schedule for NEs, i.e., MNE $=0 .{ }^{21}$ In our sample, the $€ 1.65$ million in average, additional profits reduce the ETR over the support of pre-tax profits by around 2.52 percentage points. Similarly, we can compute the distance between the ETR schedules of MNEs and NEs (the distance between points B and C in Figure 2), which gives us the footlooseness effect and is about 3.58 percentage points on average. Adding both effects produces an average overall effect of 6.10 percentage points, where the footlooseness effect contributes about $58 \%$.

We use the estimated coefficients from Table 7 to plot the ETR schedules for MNEs and NEs and the treatment effects of MNE status. However, we focus on the results using entropy balancing in Column (2). The left panel of Figure 3 now plots the ETR schedules with 95-percent confidence bounds. ${ }^{22}$ The right panel of the figure, in addition to the footlooseness effect (dotted line, the difference in the MNEs' and NEs' ETR schedules from the left-hand panel), plots the estimated size effect (dashed line) with 95-percent confidence bounds and the overall effect. Clearly, the footlooseness effect is dominant in the right tail of the pre-tax profit distribution, indicating that bigger, footloose firms are gaining more from threatening to relocate. Due to differences in the slope of the ETR schedule, the size effect is most prominent in the left tail.

\footnotetext{
${ }^{21}$ The results are qualitatively similar when using the MNEs' ETR schedule instead.

${ }^{22}$ This left-hand panel of Figure 3 is similar to Figure 2 but relies on the balanced sample to estimate the ETR schedule, which explains the minor deviations.
} 
Predicted ETR for MNEs and NEs

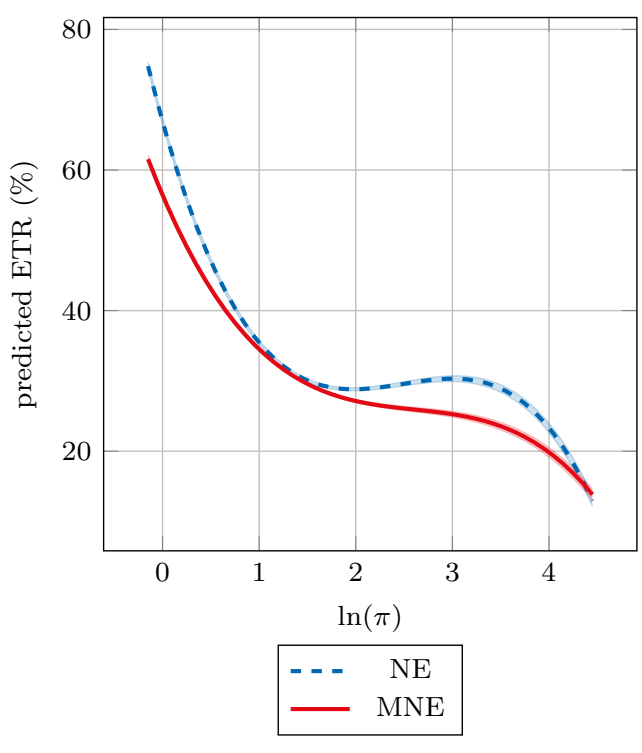

MNE treatment effects on the ETR

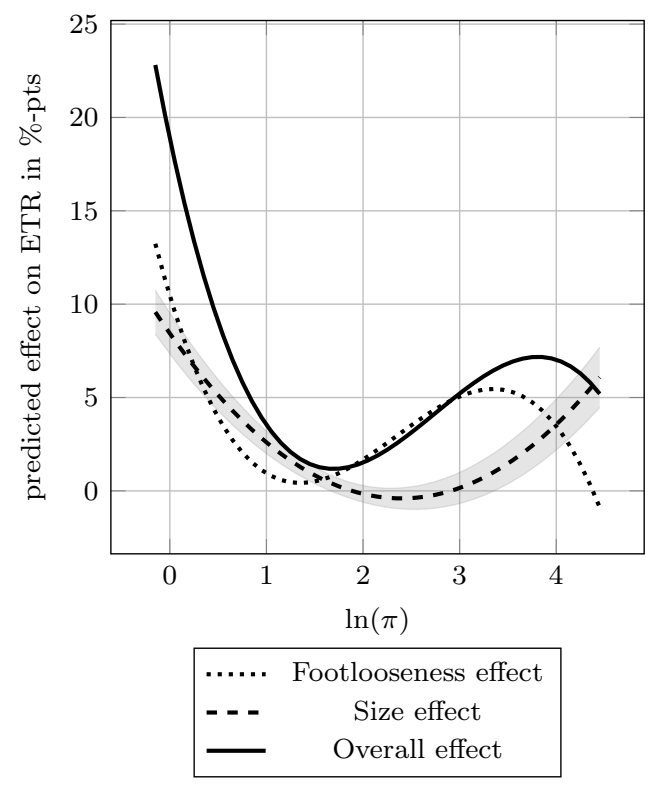

Figure 3: Balanced: Predicted EtR and treatment effect on the ETR

\subsection{Quintile regressions}

In Equation (11), we estimate a cubic relationship between ETRs and pre-tax profits, while establishing a linear relationship between the MNE status and pre-tax profits in Equation (12). However, this omits an array of possible nonlinearities in $\delta$, which we account for by applying quintile regressions for the size effect. Thus, we further constrain our sample and balance individual quintiles of the (log) pre-tax profit distribution.

Figure 4 presents quintile-specific results, estimated and balanced along pre-tax profit quintiles, and is comparable to the right-hand panel in Figure 3. Quintiles are visually separated by thin, vertical bars. In terms of pre-tax profits, the overall effect seems to be driven by the lowest and highest quintiles. MNEs in the top quintile have over $18.3 \%$ higher profits on average, which corresponds to $€ 3.84$ million in additional profits relative to NEs in the same quintile. ${ }^{23}$ In Figure 4, we derive the size effect (dashed line) using the additional profits specific to the respective quintile. In contrast to the size effect based on the whole sample, the quintile-specific size effect is now much smaller for firms in the left tail of the pre-tax profit distribution. While the slope of the ETR schedule in the left tail is very steep, small firms do not gain sufficient additional profits from being an MNE. The greater pre-tax profit gains in the right tail of the pre-tax profit distribution significantly decrease the ETR, although the slope is much smaller than in the left tail. MNEs in the highest quintile are able to reduce their ETR by 5.06 percentage points on average relative to NEs. In the top quintile, the average size effect contributes about 1.43 percentage points (or $28 \%$ percent) to the average overall effect.

Table 9 gives a detailed overview of the decomposition by quintile.

\footnotetext{
${ }^{23}$ The average firm in the highest quintile earns about $€ 21$ million in pre-tax profits.
} 

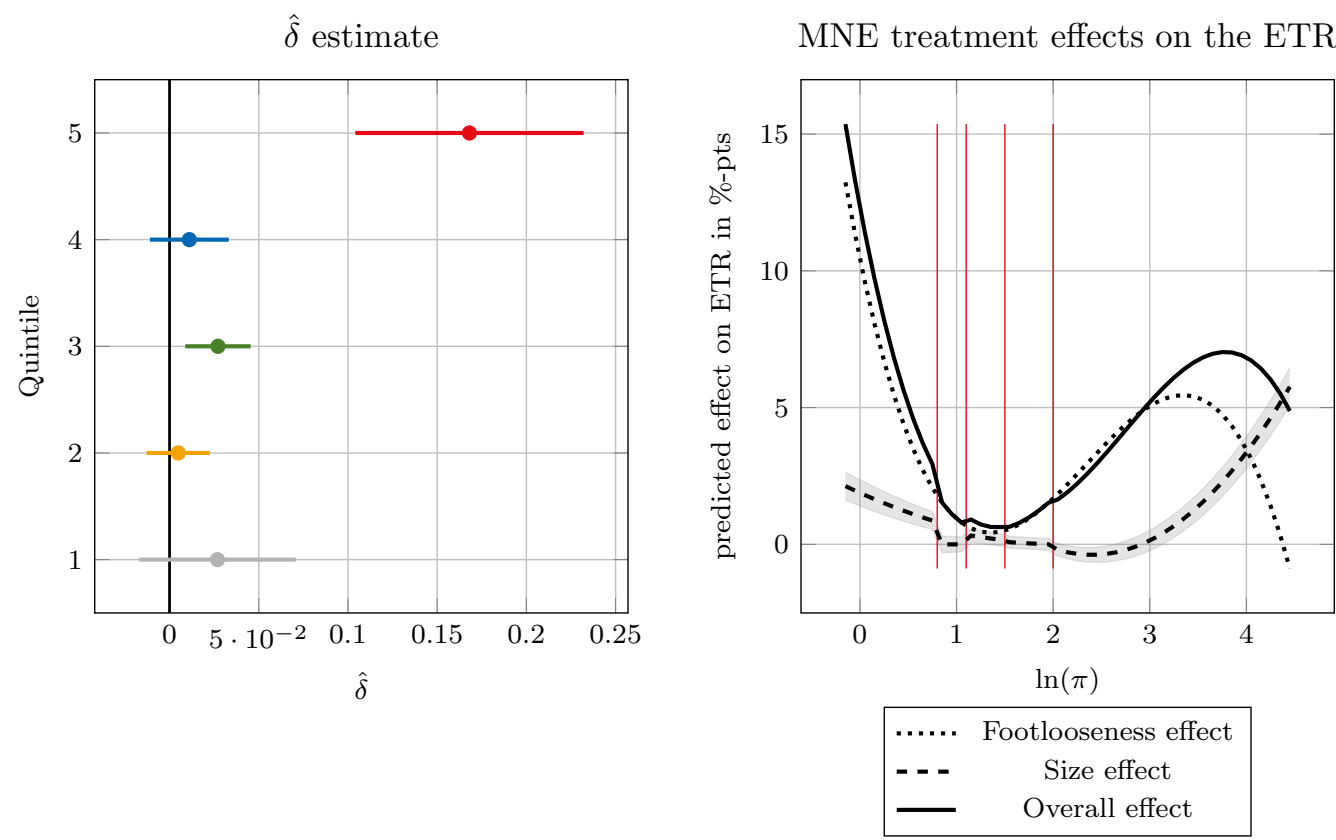

Figure 4: Balanced: Additional MNE profits and treatment effects on ETR By pre-tax PROFIT QUINTILES

Table 9: Decomposition of treatment effects by PRE-tax Profit Quintile

\begin{tabular}{c|cccc}
\hline Quintile & $\widehat{\delta}$ & Size effect & Footlooseness & Overall \\
\hline 1 & 0.04 & 1.46 & 6.71 & 8.17 \\
2 & 0.00 & 0.00 & 1.15 & 1.15 \\
3 & 0.03 & 0.24 & 0.48 & 0.72 \\
4 & 0.02 & 0.04 & 1.00 & 1.04 \\
5 & 0.17 & 1.43 & 3.63 & 5.06 \\
\hline
\end{tabular}

Decomposition of the overall effect into the size and footlooseness effects. Point estimates of $\widehat{\delta}$ are the average for each quintile.

\section{$5 \quad$ Robustness checks}

We perform various robustness checks. First, we repeat the entropy balancing estimation using a much larger sample, which includes firms with revenues over $€ 250$ million and tax payments below $€ 763,000$, in Section 5.1. This robustness check stands apart from the previous estimations in that the applicable French statutory tax rate that the firms in the sample face is no longer constant across and within firms, while all previous and subsequent samples and were and are constrained to firms with a French statutory tax rate of $34.43 \%$. We additionally use the bacon procedure by Weber (2010) to eliminate outliers, showing that the results are not driven by a few superstar firms.

Next, we account for a finding in Habu (2017), who argues that unconditional tax differentials of English MNEs and NEs arise from the incomplete consideration of MNEs with negative profits and the possibility to carry losses forward. We approach this argument in two ways. (i) We follow Habu (2017) directly and include firms with negative profits. To allow for negative profits in our estimation strategy, we use all variables in levels and set the ETR equal to zero for all firms with negative profits. Specifically, we use the same set of 
variables in our entropy balancing procedure, only in levels. Analogously, we estimate Equations (11) and (12) in levels to determine the ETR schedule and the absolute additional profits of MNEs. (ii) We follow Dyreng et al. (2017) and repeat the estimation after excluding all firms that had negative profits at any point in our sample, as well as the year 2007, as we do not observe profits before that year. This mitigates the possibility of loss carryforward but reduces the number of observations. These two checks are presented in Section 5.2.

Given the prominence of tax havens in the popular consciousness and the policy debate around profit shifting, we analyze the impact of tax havens on the benchmark results in Section 5.3. We once more approach this analysis in two ways: (i) accounting for the presence of tax havens among the parent or subsidiaries of an entity using a dummy variable and (ii) excluding firms where this same tax haven indicator is equal to 1.

Lastly, we consider that the difference in the ETRs between MNEs and NEs may be due to the use of large tax consulting firms by MNEs to handle their tax negotiations with the French tax authorities. We therefore rely on the declared auditor in Bureau van Dijk's ORBIS data to construct and include an indicator variable in the balancing model. We repeat the balancing estimation and present the corresponding results in Section 5.4 .

We generally present the regression results of the robustness checks in tables and only present graphical results in those cases where these differ significantly from the benchmark estimates. ${ }^{24}$

\subsection{Reducing the restrictions in sample selection}

Table 10: Entities in France By type: Fewer Restrictions

\begin{tabular}{l|ccc}
\hline & Entities & Obs & Percent \\
\hline Domestic multi-entity & 2,674 & 5,123 & 42.34 \\
Multinational & 3,461 & 6,977 & 57.66 \\
\hline Total & 6,135 & 12,100 & \\
\hline
\end{tabular}

In the main analysis of the paper, we work with a subsample of entities whose statutory tax rate in France is equal over the entire sample period and across all observations. However, we now maintain the complete sample of French NEs and MNEs and take their different statutory tax rates into consideration using binary indicators. ${ }^{25}$ The sample used in this section is summarized in Table 10 and is roughly 2.5 times the size of the benchmark sample.

To ensure that the results in this section are not driven by outliers, we also perform the bacon procedure developed by Weber (2010) with a generous p-value of $25 \%$. This procedure reduces the estimation sample to 11,120 firm-year observations, relative to the 12,100 observations in the fully unrestrained sample. We rerun the entropy balancing and produce the pre-tax profit balancing results both on the full unrestrained and the post-bacon procedure sample, the results of which are presented in the respective columns of Table

\footnotetext{
${ }^{24}$ We use tax payments over total assets as an alternative measure to the ETR and repeat the analysis from Section 4.4 in Section D of the online appendix. There are two advantages of using taxes over assets: (i) assets are always positive, unlike profits; and (ii) total assets fluctuate less than pre-tax pro fits, which reduces business-cycle effects in our estimations. However, tax payments over total assets are difficult to interpret economically, as the numerator of this ratio is a flow, while the denominator is a stock. Nevertheless, the results are robust to this specification.

${ }^{25}$ The respective indicators are equal to unity if the entity's statutory tax rate is equal to (i) $331 / 3 \%$, (ii) $34.43 \%$, or (iii) $36.1 \%$.
} 
11. Compared to Table 7 the coefficients are much lower due to the fact that we now include many firms with substantially higher profits.

Table 11: Balanced: Estimation of the French ETR schedule - Fewer Restrictions

\begin{tabular}{|c|c|c|c|}
\hline Variable & & $\begin{array}{c}\text { Full sample } \\
\text { (1) }\end{array}$ & $\begin{array}{c}\text { Post-bacon } \\
\text { (2) }\end{array}$ \\
\hline $\ln (\widetilde{\pi})$ & $\left(\omega_{1}\right)$ & $\begin{array}{c}0.33^{*} \\
(0.19)\end{array}$ & $\begin{array}{c}0.28 \\
(0.19)\end{array}$ \\
\hline $\ln (\widetilde{\pi})^{2}$ & $\left(\omega_{2}\right)$ & $\begin{array}{c}-0.18^{* * *} \\
(0.05)\end{array}$ & $\begin{array}{c}-0.15^{* * *} \\
(0.05)\end{array}$ \\
\hline $\ln (\tilde{\pi})^{3}$ & $\left(\omega_{3}\right)$ & $\begin{array}{c}-0.03^{* * *} \\
(0.01)\end{array}$ & $\begin{array}{c}-0.02^{* *} \\
(0.01)\end{array}$ \\
\hline$\widehat{\mathrm{MNE}}$ & $(\mu)$ & $\begin{array}{c}-3.12^{* * *} \\
(1.30)\end{array}$ & $\begin{array}{c}-3.05^{* * *} \\
(0.51)\end{array}$ \\
\hline$\widehat{\mathrm{MNE}} \times \ln (\tilde{\pi})$ & $\left(\vartheta_{1}\right)$ & $\begin{array}{c}-1.04^{* * *} \\
(0.27)\end{array}$ & $\begin{array}{c}-0.93^{* * *} \\
(0.30)\end{array}$ \\
\hline$\widetilde{\mathrm{MNE}} \times \ln (\widetilde{\pi})^{2}$ & $\left(\vartheta_{2}\right)$ & $\begin{array}{l}0.13^{* *} \\
(0.07)\end{array}$ & $\begin{array}{c}0.03 \\
(0.07)\end{array}$ \\
\hline$\widehat{\mathrm{MNE}} \times \ln (\widetilde{\pi})^{3}$ & $\left(\vartheta_{3}\right)$ & $\begin{array}{l}0.03^{* * *} \\
(0.01)\end{array}$ & $\begin{array}{c}0.02 \\
(0.02)\end{array}$ \\
\hline Constant & $(v)$ & $\begin{array}{l}28.14^{* * *} \\
(0.37)\end{array}$ & $\begin{array}{l}28.08^{* * *} \\
(0.37)\end{array}$ \\
\hline $\begin{array}{l}\text { F-statistic } \\
\text { Observations }\end{array}$ & & $\begin{array}{r}4.50 \\
12,100\end{array}$ & $\begin{array}{r}13.18 \\
11,120\end{array}$ \\
\hline
\end{tabular}

Standard errors in parentheses obtained through bootstrapping. ***, **, and * indicate levels of statistical significance at 1,5 , and 10 percent, respectively. F-statistic is for the joint significance of all MNE effects.

We also re-estimate the additional MNE profits, $\widehat{\delta}$, based on these two new samples of firms. Without balancing, $\widehat{\delta}$ is 2.17 (with a standard error of 0.03 ) in the full sample and 2.15 (with a standard error of 0.03 ) in the post-bacon sample. However, after applying entropy balancing on firm fundamentals, $\widehat{\delta}$ amounts to 0.63 (and a standard error of 0.04) in the full sample and 0.64 (with a standard error of 0.04) in the postbacon procedure sample. Comparing the results for the full sample and the results after applying Weber's bacon procedure leaves us confident that outliers in the full sample do not drive the results.

Recall that the full unrestrained sample allows for all profits greater than 0 and $\ln (\pi)$ is defined as the $\log$ of profits in millions, MNEs with extremely low profits do face higher ETRs than comparable NEs. Additionally, the frequency of MNEs at such low profits is far lower than for NEs. Figure 5 presents the estimated size and overall effect for this unrestrained sample, based on Column (1) in Table 11. The estimated size effect is insignificant for the majority of firms in the sample. ${ }^{26}$

\footnotetext{
${ }^{26}$ A plot based on the bacon-procedure results in Column (2) is very similar, with an insignificant size effect throughout; we therefore forgo presenting these results in the interest of space.
} 
Predicted ETR for MNEs and NEs

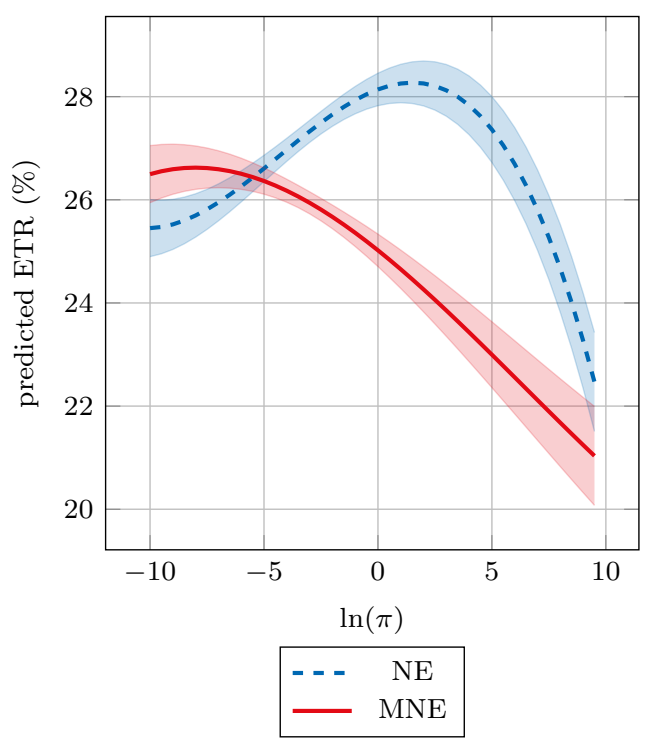

MNE treatment effects on the ETR

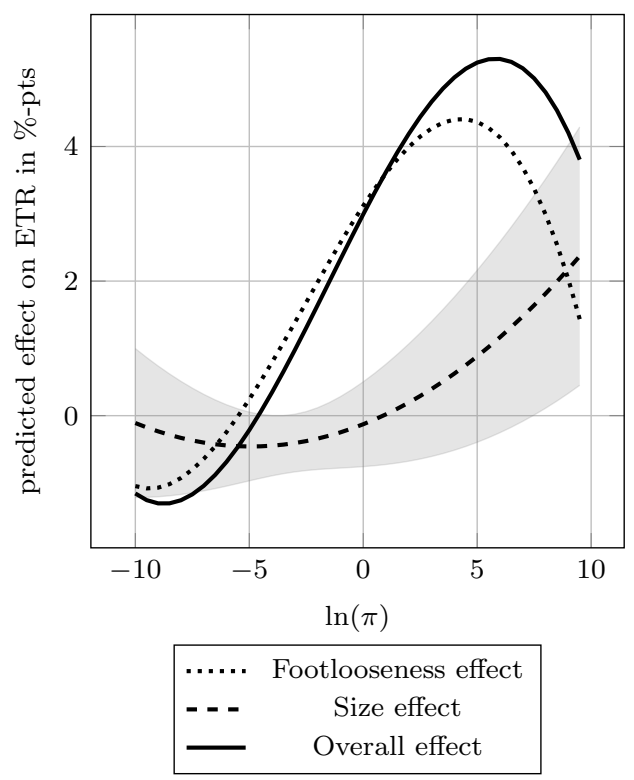

Figure 5: Balanced: Predicted ETR and treatment effect on the ETR - Fewer Restrictions

The results above indicate that the benchmark results are not an artifact of our sample selection on the French statutory tax rate. Permitting firms to be positioned at any point on the statutory tax schedule results in qualitatively similar, while quantitatively smaller, effects. Similarly, applying the bacon procedure in the unrestrained sample leaves the main findings intact.

\subsection{Negative profits}

For the first part of this robustness check we include firms with negative profits in the estimation sample. This requires an estimation in levels and not logs. Moreover, as negative ETRs are not possible, we set instances of negative ETRs equal to zero. This results in different estimated ETR schedules of NEs and MNEs. The great mass of firms with an ETR of zero in the data leads to an upward sloping ETR schedule in the left tail. However, the right tail of the ETR schedules looks very similar to the benchmark case. Even when including MNEs with negative pre-tax profits, MNEs are (on average) still more profitable than similar NEs and their additional pre-tax profits are about $€ 300,000$. This result is once again mainly driven by firms in the top quintile of the pre-tax profit distribution which have $€ 500,000$ in additional profits relative to comparable NEs.

For the second part of this robustness check we deal with tax loss carryforwards (or net operating loss carryforwards) by eliminating data from the year 2007 as well as all firms that made losses at any point in the sample period. This reduces our sample by about 17 percent to 2,037 entities (3,792 firm-year observations), of which 1,530 entities (2,617 firm-year observations) are domestic multi-entity firms and 537 entities (1,106 firm-year observations) are multinational firms, or 70.3 and 29.7 percent, respectively. We rerun the entropy balancing based on this reduced sample and produce the pre-tax profit balancing results presented in Table 12. 
Table 12: Balanced: Estimation of the French ETR schedule - No loss Carryforward

\begin{tabular}{|c|c|c|}
\hline \multicolumn{2}{|l|}{ Variable } & Coef. \\
\hline $\ln (\widetilde{\pi})$ & $\left(\omega_{1}\right)$ & $\begin{array}{c}-47.37^{* * *} \\
(6.15)\end{array}$ \\
\hline $\ln (\tilde{\pi})^{2}$ & $\left(\omega_{2}\right)$ & $\begin{array}{l}20.34^{* * *} \\
(3.32)\end{array}$ \\
\hline $\ln (\widetilde{\pi})^{3}$ & $\left(\omega_{3}\right)$ & $\begin{array}{c}-2.78^{* * *} \\
(0.55)\end{array}$ \\
\hline$\widehat{\mathrm{MNE}}$ & $(\mu)$ & $\begin{array}{c}-8.84^{* *} \\
(5.72)\end{array}$ \\
\hline$\widehat{\mathrm{MNE}} \times \ln (\widetilde{\pi})$ & $\left(\vartheta_{1}\right)$ & $\begin{array}{l}15.91^{* *} \\
(9.10)\end{array}$ \\
\hline$\widehat{\mathrm{MNE}} \times \ln (\widetilde{\pi})^{2}$ & $\left(\vartheta_{2}\right)$ & $\begin{array}{c}-9.05^{* *} \\
(4.46)\end{array}$ \\
\hline$\widetilde{\mathrm{MNE}} \times \ln (\widetilde{\pi})^{3}$ & $\left(\vartheta_{3}\right)$ & $\begin{array}{c}1.36^{*} \\
(0.68)\end{array}$ \\
\hline Constant & $(v)$ & $\begin{array}{l}64.93^{* * *} \\
(3.46)\end{array}$ \\
\hline $\begin{array}{l}\text { F-statistic } \\
\text { Observations }\end{array}$ & & $\begin{array}{l}24.25 \\
3,722\end{array}$ \\
\hline
\end{tabular}

Standard errors in parentheses obtained through bootstrapping. ***, **, and * indicate levels of statistical significance at 1, 5, and 10 percent, respectively. F-statistic is for the joint significance of all MNE effects.

The new sample is then also used for a new estimation of additional MNE profits, $\widehat{\delta}$. Without balancing, pre-tax profits are about $51 \%$ (coefficient of 0.41 with a standard error of 0.03 ) higher for MNEs, while entropy balancing reduces this difference to about $27 \%$ (coefficient of 0.24 with a standard error of 0.03 ). The overall results for the predicted ETR schedules for MNEs and NEs and the MNE treatment effects on the ETR are consistent with the benchmark results. We are therefore confident that the results are not an artifact of insufficiently accounting for loss-making firms and that loss carryforward does not exacerbate the tax differences found in the benchmark results.

Taken together, the robustness checks permitting negative profits and eliminating negative profits lead us to conclude that MNEs have systematically higher profits than comparable domestic firms and thus lower ETRs. Our main results are therefore unchanged. In fact, domestic firms have systematically higher losses and more frequently carry losses forward than comparable MNEs, which biases the ETR in favor of domestic firms and would suggest that our results are the lower bound. ${ }^{27}$

\subsection{The effect of tax havens}

To account for the significance of tax havens among the foreign subsidiary/parent countries, we address their presence in two alternative ways: (i) we condition on a tax haven indicator and (ii) exclude firms with tax haven subsidiaries/parents. In both cases, we define a tax haven indicator, based on the list of countries in

\footnotetext{
${ }^{27}$ This may also suggest that French domestic-only firms were more severely affected by the financial crisis of 2008 .
} 
Dharmapala and Hines (2009), which is unity if the parent or an affiliated firm of a company is located in a tax haven country on that list.

When pursuing the first strategy and conditioning on the tax haven indicator, the sample size is unaffected relative to the benchmark analysis in Section 4.4. In the re-estimation of Equation (7), the tax haven indicator carries a statistically insignificant coefficient and the $\mathrm{EATR}_{i t}^{\prime}$ variable loses some of its significance (see the results in Columns (1)-(3) in Table 13).

Table 13: EFFECT OF FOREIGN TAXES ON A FIRM'S ETR BY OWNERSHIP STRUCTURE: TAX HAVENS

\begin{tabular}{|c|c|c|c|c|c|c|c|}
\hline & & & Indicator approa & & & Tax haven exclus & ion \\
\hline Varia & & $\begin{array}{l}\text { All MNEs } \\
\text { (1) }\end{array}$ & $\begin{array}{l}\text { Foreign parents } \\
\qquad(2)\end{array}$ & $\begin{array}{c}\text { French parents } \\
(3)\end{array}$ & $\begin{array}{l}\text { All MNEs } \\
(4)\end{array}$ & $\begin{array}{c}\text { Foreign parents } \\
(5)\end{array}$ & $\begin{array}{c}\text { French parents } \\
\text { (6) }\end{array}$ \\
\hline $\ln \left(\pi_{i t}\right)$ & $\left(\beta_{1}\right)$ & $\begin{array}{c}-54.87^{* * *} \\
(7.86)\end{array}$ & $\begin{array}{c}-57.59^{* * *} \\
(11.08)\end{array}$ & $\begin{array}{c}-42.57^{* * *} \\
(7.99)\end{array}$ & $\begin{array}{c}-54.39^{* * *} \\
(8.79)\end{array}$ & $\begin{array}{c}-58.25^{* * *} \\
(12.49)\end{array}$ & $\begin{array}{c}-39.77^{* * *} \\
(8.47)\end{array}$ \\
\hline $\ln \left(\pi_{i t}\right)^{2}$ & $\left(\beta_{2}\right)$ & $\begin{array}{l}21.77^{* * *} \\
(3.70)\end{array}$ & $\begin{array}{l}23.07^{* * *} \\
(5.32)\end{array}$ & $\begin{array}{l}15.64^{* * *} \\
(3.87)\end{array}$ & $\begin{array}{l}21.64^{* * *} \\
(4.11)\end{array}$ & $\begin{array}{l}23.44^{* * *} \\
(5.89)\end{array}$ & $\begin{array}{l}14.51^{* * *} \\
(4.10)\end{array}$ \\
\hline $\ln \left(\pi_{i t}\right)^{3}$ & $\left(\beta_{3}\right)$ & $\begin{array}{c}-2.81^{* * *} \\
(0.54)\end{array}$ & $\begin{array}{l}-2.96^{* * *} \\
(0.80)\end{array}$ & $\begin{array}{c}-1.93^{* * *} \\
(0.57)\end{array}$ & $\begin{array}{c}-2.78^{* * *} \\
(0.60)\end{array}$ & $\begin{array}{c}-3.00^{* * *} \\
(0.87)\end{array}$ & $\begin{array}{c}-1.78^{* * *} \\
(0.61)\end{array}$ \\
\hline $\mathrm{EATR}_{i t}^{\prime}$ & $(\varphi)$ & $\begin{array}{l}0.32^{* *} \\
(0.16)\end{array}$ & $\begin{array}{l}0.30^{* *} \\
(0.15)\end{array}$ & $\begin{array}{c}0.14 \\
(0.22)\end{array}$ & $\begin{array}{c}0.25 \\
(0.16)\end{array}$ & $\begin{array}{c}0.29 \\
(0.19)\end{array}$ & $\begin{array}{c}0.04 \\
(0.22)\end{array}$ \\
\hline Tax have & & $\begin{array}{l}9.52 \\
(6.03)\end{array}$ & $\begin{array}{l}1.87 \\
(3.15)\end{array}$ & $\begin{array}{r}-8.77 \\
(8.99)\end{array}$ & & & \\
\hline Constant & $(v)$ & $\begin{array}{l}69.81^{* * *} \\
(5.45)\end{array}$ & $\begin{array}{l}65.46^{* * *} \\
(9.16)\end{array}$ & $\begin{array}{l}63.08^{* * *} \\
(5.42)\end{array}$ & $\begin{array}{l}69.47^{* * *} \\
(6.10)\end{array}$ & $\begin{array}{l}66.29^{* * *} \\
(10.24)\end{array}$ & $\begin{array}{l}61.72^{\text {*** }} \\
(5.69)\end{array}$ \\
\hline$R^{2}$ & & 0.32 & 0.31 & 0.32 & 0.31 & 0.25 & 0.31 \\
\hline Observat & & 1,415 & 612 & 985 & 952 & 535 & 560 \\
\hline
\end{tabular}

Only those foreign markets with an affiliate with the lowest foreign EATR' considered. Columns (1)-(3) account for the presence of tax haven affiliates through Tax haven, an indicator for affiliates or parents in a tax haven country. Columns (4)-(6) excludes firms with parents/affiliates in tax haven countries. The sample for foreign headquarters uses French MNE units which are headquartered abroad, irrespective of whether they hold foreign affiliates themselves or not. The sample for French parents uses French MNE units which hold affiliates abroad, irrespective of whether they themselves are headquartered in France or abroad. Hence, there is some overlap between these samples. Standard errors in parentheses clustered at firm level. We suppress estimates of the lowest-tax-country-in-i's-network, time-, and sector-fixed effects. ***, **, and * indicate levels of statistical significance at 1, 5, and 10 percent, respectively.

However, when following the second approach and dropping firms with entities (affiliates or parents) in tax havens, the number of observations is reduced to 4,095 (compared to 4,661 in the benchmark analysis) and the parameter on EATR ${ }_{i t}^{\prime}$ loses in significance (see the results in Columns (4)-(6) in Table 13). This should not come as a surprise, as conditioning on a tax haven indicator or, more so, eliminating tax-haven-affiliated units inevitably leads to a reduction in the conditional variance of $\mathrm{EATR}_{i t}^{\prime}$.

Since the tax haven indicator is not statistically significant, we perform the entropy balancing and estimate the French ETR schedule after excluding firms with parents or subsidiaries in tax haven countries. The results in Table 14 are largely unaffected relative the benchmark analysis in Table 7 . In the estimation of the ATE of MNE status on firms' profits, $\widehat{\delta}$ amounts to $37 \%$ (coefficient of 0.32 with a standard error of 0.02 ) before balancing and to $15 \%$ (coefficient of 0.14 with a standard error of 0.03 ) after balancing. By extension, the results of the predicted ETR and treatment effects on the ETR are robust to the exclusion of tax haven entities. 
Table 14: Balanced: Estimation of the French ETR SCHEDUle - Exclusion of FiRms with PARENTS/AFFILIATES IN TAX HAVENS

\begin{tabular}{|c|c|c|}
\hline \multicolumn{2}{|l|}{ Variable } & Coef. \\
\hline $\ln \left(\widetilde{\pi_{i t}}\right)$ & $\left(\omega_{1}\right)$ & $\begin{array}{c}-47.78^{* * *} \\
(4.42)\end{array}$ \\
\hline $\ln \left(\widetilde{\pi_{i t}}\right)^{2}$ & $\left(\omega_{2}\right)$ & $\begin{array}{l}19.92^{* * *} \\
(2.31)\end{array}$ \\
\hline $\ln \left(\widetilde{\pi_{i t}}\right)^{3}$ & $\left(\omega_{3}\right)$ & $\begin{array}{c}-2.63^{* * *} \\
(0.37)\end{array}$ \\
\hline$\widehat{\mathrm{MNE}_{i t}}$ & $(\mu)$ & $\begin{array}{c}-9.10^{*} \\
(5.29)\end{array}$ \\
\hline$\widetilde{\mathrm{MNE}_{i t}} \times \ln \left(\widetilde{\pi_{i t}}\right)$ & $\left(\vartheta_{1}\right)$ & $\begin{array}{l}15.08^{*} \\
(8.53)\end{array}$ \\
\hline$\widetilde{\mathrm{MNE}_{i t}} \times \ln \left(\widetilde{\pi_{i t}}\right)^{2}$ & $\left(\vartheta_{2}\right)$ & $\begin{array}{r}-8.06^{*} \\
(4.22)\end{array}$ \\
\hline${\widetilde{\mathrm{MNE}_{i t}}} \times \ln \left(\widetilde{\pi_{i t}}\right)^{3}$ & $\left(\vartheta_{3}\right)$ & $\begin{array}{c}1.17^{*} \\
(0.64)\end{array}$ \\
\hline Constant & $(v)$ & $\begin{array}{l}65.79^{* * *} \\
(2.58)\end{array}$ \\
\hline $\begin{array}{l}\text { F-statistic } \\
\text { Observations }\end{array}$ & & $\begin{array}{l}16.17 \\
4,095\end{array}$ \\
\hline
\end{tabular}

Standard errors in parentheses obtained through bootstrapping. ***, **, and $*$ indicate levels of statistical significance at 1, 5, and 10 percent, respectively. F-statistic is for the joint significance of all MNE effects. See Dharmapala and Hines, 2009 for a list of tax havens that were used in the exclusion.)

\subsection{Firms which use the Big-Four consulting firms}

One of the reasons for the large difference in ETRs between MNEs and NEs may be MNEs' disproportionate use of large tax consulting firms, the Big-Four: Deloitte, Ernst \& Young, KPMG, and PricewaterhouseCoopers, to handle their tax negotiations and auditing. Given their extensive network and expertise, the Big-Four could enable, facilitate, or improve the bargaining of firms with the local tax authorities. To test this hypothesis, we constructed a Big-Four dummy variable (based on the declared auditor in the ORBIS data) and re-estimated both the entropy balancing and the subsequent regressions based on an augmented model that accounts for the use of a Big-Four firm. In $44 \%$ of the firm-year observations in our sample, one of the Big-Four auditors is used. The usage between MNEs and NEs is remarkably similar at 43\% and 44.5\%, respectively. Hence, MNEs do not disproportionately rely on Big-Four accounting firms. Still, we present the results for the estimated French tax schedule in Table 15. We also re-estimated the (OLS-based) unbalanced and (entropy-) balanced ATE of the MNE status: the parameer amounts to $48 \%$ (coefficient of 0.39 with a standard error of 0.02 ) without covariate balancing and to $18 \%$ (coefficient of 0.17 with a standard error of 0.03) with covariate balancing. The findings after conditioning on the Big-Four indicator variable are very similar to the previous benchmark findings. This result is quite striking, as the Big- Four-controlled sample is much smaller than the benchmark sample (2,904 versus 4,661 firm-year observations). Moreover, the statistical significance appears to increase in spite of the reduction in the degrees of freedom. The results 
of the predicted ETR and the treatment effects on the ETR are also robust to accounting for the use of firms relying on the Big-Four consultants only.

Table 15: Balanced: Estimation of the French ETR schedule - Controlling for usage of BIG-Four

\begin{tabular}{|c|c|c|}
\hline \multicolumn{2}{|l|}{ Variable } & Coef. \\
\hline $\ln \left(\widetilde{\pi_{i t}}\right)$ & $\left(\omega_{1}\right)$ & $\begin{array}{c}-69.73^{* * *} \\
(3.73)\end{array}$ \\
\hline $\ln \left(\widetilde{\pi_{i t}}\right)^{2}$ & $\left(\omega_{2}\right)$ & $\begin{array}{l}29.91^{* * *} \\
(1.87)\end{array}$ \\
\hline $\ln \left(\widetilde{\pi_{i t}}\right)^{3}$ & $\left(\omega_{3}\right)$ & $\begin{array}{c}-4.07^{* * *} \\
(0.29)\end{array}$ \\
\hline$\widehat{\mathrm{MNE}_{i t}}$ & $(\mu)$ & $\begin{array}{c}-8.16^{* *} \\
(3.38)\end{array}$ \\
\hline$\widetilde{\mathrm{MNE}_{i t}} \times \ln \left(\widetilde{\pi_{i t}}\right)$ & $\left(\vartheta_{1}\right)$ & $\begin{array}{l}16.69^{* * *} \\
(3.38)\end{array}$ \\
\hline$\widetilde{\mathrm{MNE}_{i t}} \times \ln \left(\widetilde{\pi_{i t}}\right)^{2}$ & $\left(\vartheta_{2}\right)$ & $\begin{array}{c}-9.86^{* * *} \\
(2.48)\end{array}$ \\
\hline$\widetilde{\mathrm{MNE}}_{i t} \times \ln \left(\widetilde{\pi_{i t}}\right)^{3}$ & $\left(\vartheta_{3}\right)$ & $\begin{array}{l}1.55^{* * *} \\
(0.37)\end{array}$ \\
\hline Constant & $(v)$ & $\begin{array}{l}80.87^{* * *} \\
(2.30)\end{array}$ \\
\hline $\begin{array}{l}\text { F-statistic } \\
\text { Observations }\end{array}$ & & $\begin{array}{c}15.24 \\
2,904\end{array}$ \\
\hline
\end{tabular}

Standard errors in parentheses obtained through bootstrapping. ***, **, and ${ }^{*}$ indicate levels of statistical significance at 1, 5, and 10 percent, respectively. F-statistic is for the joint significance of all MNE effects.

\section{Conclusions}

This paper investigates the differences in the effective tax rates (ETRs) of French multinational enterprises (MNEs) vis-á-vis French domestic-only, national enterprises (NEs). MNEs are in a better bargaining position in their negotiations with tax authorities due to both their size and their reduced relocation costs relative to NEs. We formalize this idea in a simple stylized model, where firms and tax authorities negotiate over tax deductions. Firms with higher pre-tax profits and lower fixed costs of relocating have a better bargaining position and hence have lower ETRs. Moreover, the stylized model implies that the ETR schedule is regressive, specifically due to the increased bargaining power of more profitable firms. As MNEs have, on average, higher pre-tax profits, their bargaining power is higher and hence their ETRs are lower. We refer to this as the size effect. On the other hand, the footlooseness effect accounts for how much the effective tax rate of MNEs decreases due to their lower fixed relocation costs and, thus, their higher credibility in threatening to move their operations abroad relative to NEs.

In this paper, we argue that the unequal treatment of MNEs by French tax authorities, manifested in the aforementioned bargaining channel, reduces MNEs' ETRs relative to comparable NEs - even after controlling 
for possible profit shifting through the usual channels: debt shifting, patent trading, and transfer pricing. Advance tax rulings (especially undisclosed ones) are an obvious candidate in the more favorable treatment of MNEs relative to NEs. On the other hand, it appears implausible that tax authorities acting on good faith systematically err on the side of MNEs as both MNEs and NEs are able to obtain advance tax ruling and appeal unfavourable ones. Given that the footlooseness effect is increasing with firm size, it is furthermore implausible that the difference in the ETR between MNEs and NEs can be exclusively attributed to a selection of MNEs into France due to favorable advance tax rulings and non-selection in the case of unfavorable rulings. If the tax authorities act on good faith with a random error, we would expect that the footlooseness effect is constant over the firm size distribution. The stylized model suggests that footlooseness interacts with pre-tax profits and, hence, we would expect that the footlooseness effect is greater for (everything else being equal) more profitable firms. This is consistent with the empirical findings and clearly suggests the existence and relevance of the bargaining channel.

Empirically, we find that an average (French or foreign) MNE in France faces a 3.42 percentage point lower (pre-balancing) effective tax rate than a French firm with purely domestic operations. In order to decompose the overall effect into its footlooseness- and size-related components, we compare MNEs and NEs that are otherwise identical using entropy balancing. While the footlooseness effect amounts to, on average, 3.58 percentage points, the size effect corresponds to a 2.52 percentage point reduction in the ETR of MNEs. In total, the conditional difference in the ETR between comparable MNE and NE entities amounts to 6.1 percentage points. Moreover, we find that the total bargaining effect of being an MNE on the ETR is mainly driven by high-productivity (high-profit) firms.

Beginning in 2015, the European Commission ramped up its efforts to investigate and overrule its member states' tax rulings if these are found to provide "selective, unfair competitive advantage" and therefore constitute "prohibited state aid" (see Bloomberg Tax, 2018). These efforts limit countries' ability to set and determine their own tax policy. However, the establishment and enforcement of global tax avoidance agreements appears to call for constraining individual governments in their freedom to circumvent global rules they agreed to by negotiating local deals. 


\section{References}

Becker, J. and N. Riedel, "Cross-border tax effects on affiliate investment - Evidence from European multinationals," European Economic Review, 2012, 56 (3), 436-450.

Bergin, J., "Amazon receives $\$ 252$ million back tax claim," Reuters, 12 November 2012.

Bloomberg Tax, "European commission targets member states' tax rulings as prohibited state aid: Where will it lead?," Bureau of National Affairs, Inc., 25 January 2018.

Boesenberg, S. and P.H. Egger, "R\&D tax incentives and the emergence and trade of ideas," Economic Policy, 2016, 32 (89), 39-80.

_, _, and B. Zoller-Rydzek, "Capital taxation, investment, growth, and welfare," International Tax and Public Finance, 2018, 25 (2), 325-376.

Brinded, L., "Tax avoidance crackdown: France to force companies to reveal foreign activity and bills," International Business Times, 3 June 2013.

Buettner, T., M. Overesch, U. Schreiber, and G. Wamser, "Taxation and capital structure choice Evidence from a panel of German multinationals," Economics Letters, 2009, 105 (3), 309-311.

Clift, B., "Comparative capitalisms, ideational political economy and French post-dirigiste responses to the global financial crisis," New Political Economy, 2012, 17 (5), 565-590.

Cullen, D., "EU sues France over illegal France Telecom aid - The mother of all tax breaks," The Register, 19 July 2006.

Davies, R.B, J. Martin, M. Parenti, and F. Toubal, "Knocking on tax haven's door: Multinational firms and transfer pricing," The Review of Economics and Statistics, 2018, 100 (1), 120-134.

Devereux, M.P and G. Maffini, "The impact of taxation on the location of capital, firms and profit: A survey of empirical evidence," Oxford University Centre for Business Taxation Working Paper Series, 2007, 07/02.

Devereux, M.P. and R. Griffith, "The taxation of discrete investment choices," IFS Working Papers, 1998, W98/16.

- and _, "Evaluating tax policy for location decisions," International Tax and Public Finance, 2003, 10 (2), 107-126.

Devereux, M.P, R. Griffith, and A. Klemm, "The impact of taxation on the location of capital, firms and profit: A survey of empirical evidence," Economic Policy, 2002, 17 (35), 449-495.

Dharmapala, D. and J.R. Hines Jr., "Which countries become tax havens?," Journal of Public Economics, 2009, 93, 1058-1068.

- and N. Riedel, "Earnings shocks and tax-motivated income-shifting: Evidence from European multinationals," Journal of Public Economics, 2013, 97, 95-107.

Direction de l'Information Légale et Administrative, "Loi N. 2013-1117 du 6 décembre 2013 relative á la lutte contre la fraude fiscale et la grande délinquance économique et financière," Journal Officiel de la République Française, 2013, 0284 (4), 19941. 
Direction Générale des Finances Publiques, "Annuaire statistique 2016," 2016. Web. 2016-02-21.

_ , "Overview of the French tax system - Legislation in force as at 31 December 2016," Technical Report 2016.

Dyreng, S.D., M. Hanlon, E.L. Maydew, and J.R. Thornock, "Changes in corporate effective tax rates over the past twenty-five years," Journal of Financial Economics, 2017, 124 (3), 441-463.

Egger, P.H., C. Keuschnigg, V. Merlo, and G. Wamser, "Corporate taxes and internal borrowing within multinational firms," American Economic Journal: Economic Policy, 2014, 6 (2), 54-93.

_, D. Radulescu, and N.M. Strecker, "Effective labor taxation and the international location of headquarters," International Tax and Public Finance, 2013, 20 (4), 631-652.

_, R. Riezman, and B. Zoller-Rydzek, "Multi-unit firms and their scope and location decision," March 2018. mimeo.

_, W. Eggert, and H. Winner, "Saving taxes through foreign plant ownership," Journal of International Economics, 2010, 81 (1), 99-108.

Escaut, P., M. Hublot, and E. Bonneaud, "France," in N. Raby, ed., International transfer pricing 2012, PricewaterhouseCoopers International Limited, 2012, pp. 405-428.

European Commission, "State aid: Commission opens in-depth investigations into tax exemptions for Belgian and French ports," Press Release, 8 July 2016.

Gresik, T.A, "The taxing task of taxing transnationals," Journal of Economic Literature, 2001, 39 (3), $800-838$.

Griffith, R., H. Miller, and M. O'Connell, "Ownership of intellectual property and corporate taxation," Journal of Public Economics, 2014, 112, 12-23.

Grubert, H. and J. Slemrod, "The effect of taxes on investment and income shifting to Puerto Rico," The Review of Economics and Statistics, 1998, 80 (3), 365-373.

Habu, K.A., "How much tax do companies pay in the UK? Evidence from UK confidential corporate tax returns," Oxford University Centre for Business Taxation Working Paper Series, 2017, 17/14.

Hainmueller, J., "Entropy balancing for causal effects: A multivariate reweighting method to produce balanced samples in observational studies," Political Analysis, 2012, 20 (1), 25-46.

- and Y. Xu, "Ebalance: A Stata package for entropy balancing," Journal of Statistical Software, 2013, $54(7)$.

Helpman, E., M.J. Melitz, and S.R. Yeaple, "Export versus FDI with heterogeneous firms," American Economic Review, 2004, 94 (1), 300-316.

Hines, J.R., "Lessons from behavioral responses to international taxation," National Tax Journal, 1999, 52 (2), 305-322.

Huesecken, B. and M. Overesch, "Tax avoidance through advance tax rulings-evidence from the LuxLeaks firms," 2015. mimeo. 
Huizinga, H. and L. Laeven, "International profit shifting within multinationals: A multi-country perspective," Journal of Public Economics, 2008, 92 (5-6), 1164-1182.

ITRWeek, "Vivendi strikes deal on French taxes," International Tax Review, 30 August 2004.

Jog, V. and J. Tang, "Tax reforms, debt shifting and tax revenues: Multinational corporations in Canada," International Tax and Public Finance, 2001, 8 (1), 5-25.

Karkinsky, T. and N. Riedel, "Corporate taxation and the choice of patent location within multinational firms," Journal of International Economics, 2012, 88 (1), 176-185.

Konrad, K.A. and T.B.M. Stolper, "Coordination and the fight against tax havens," Journal of International Economics, 2016, 103 (Supplement C), 96-107.

Kopczuk, W., "Tax simplification and tax compliance: An economic perspective," in M. Sawicky, ed., Bridging the Tax Gap: Addressing the Crisis in Tax Administration, Economic Policy Institute, 2006, pp. 111-143.

Lassmann, A. and B. Zoller-Rydzek, "Decomposing the margins of transfer pricing," 2018. mimeo.

Le Monde, "Le pratron de Google reçu par Nicolas Sarkozy," Le Monde Technologies, 9 September 2010.

_ , "Intérèt confirmé d'Amazon pour la Bourgogne," Le Monde Économie, 8 June 2012.

Levinsohn, J. and A. Petrin, "Estimating production functions using inputs to control for unobservables," The Review of Economic Studies, 2003, 70 (2), 317-341.

Markusen, J., Multinational firms and the theory of international trade, MIT Press, 2002.

Mundlak, Y., "On the pooling of time series and cross section data," Econometrica, 1978, 46 (1), 69-85.

Olley, S.G. and A. Pakes, "The dynamics of productivity in the telecommunications equipment industry," Econometrica, 1996, 64 (6), 1263-1297.

Petrin, A., B.P. Poi, and J. Levinsohn, "Production function estimation in Stata using inputs to control for unobservables," Stata Journal, 2004, 4, 113-123.

Rego, S.O., "Tax-avoidance activities of U.S. multinational corporations," Contemporary Accounting Research, 2003, 20 (4), 805-833.

Richter, B.K., K. Samphantharak, and J.F. Timmons, "Lobbying and taxes," American Journal of Political Science, 2009, 53 (4), 893-909.

Riedel, N. and M. Simmler, "Large and influential: Firm size and governments' corporate tax rate choice," CESifo Working Paper Series, 2018, 6904.

Schindler, D. and G. Schjelderup, "Transfer pricing and debt shifting in multinationals," CESifo Working Paper Series, 2013, 4381.

Slemrod, J., "The economics of corporate tax selfishness," National Tax Journal, 2004, 57 (4), 877-899.

Tørsløv, T.R., L.S. Wier, and G. Zucman, "The missing profits of nations," NBER Working Paper Series, 2018, 24701. 
Van de Velde, E., "Tax rulings' in the EU member states," Study for the ECON Committee of Directorate General for Internal Policies-Policy Department A: Economic and Scientific Policy, 2015.

Vandenbussche, H. and C. Tan, "The taxation of multinationals: Firm level evidence for Belgium," LICOS discussion paper, 2005.

Waerzeggers, C. and C. Hillier, "Introducing an advance tax ruling (ATR) regime," Tax Law IMF Technical Note, IMF February 2016.

Weber, S., "bacon: An effective way to detect outliers in multivariate data using Stata (and Mata)," Stata Journal, 2010, 10 (3), 331-338.

Wooldridge, J.M., "Inverse probability weighted estimation for general missing data problems," Journal of Econometrics, 2007, 141 (2), 1281-1301. 